\title{
Transgene-free hematopoietic stem and progenitor cells from human induced pluripotent stem cells.
}

Laurence Guyonneau-Harmand ${ }^{1,2,3}$, Bruno L'Homme ${ }^{4}$, Brigitte Birebent ${ }^{3}$, Christophe Desterke $^{5,6}$, Nathalie Chevallier ${ }^{3,7,8}$, Loïc Garçon ${ }^{1,2}$, Hélène Lapillonne ${ }^{1,2,9}$, Marc Benderitter ${ }^{4}$, François Delhommeau $^{1,2}$, Thierry Jaffredo ${ }^{10 *}$, Alain Chapel $^{1,2,4 *}$ and Luc Douay ${ }^{1,2,3,9}$

${ }^{1}$ UPMC Univ Paris 06, UMR_S938 CDR Saint-Antoine, Prolifération et Différenciation des Cellules Souches, F-75012 Paris, France.

2 INSERM, UMR_S938, Prolifération et Différenciation des Cellules Souches, F-75012 Paris, France.

${ }^{3}$ EFS Ile de France, Unité d'Ingénierie et de Thérapie Cellulaire, Créteil, F-94017, France.

${ }^{4}$ IRSN, PRP-HOM, SRBE, Laboratoire de recherche en régénération des tissus sains irradiés (LR2I), F-92262 Fontenay-aux-Roses, France.

${ }^{5}$ University Paris Sud 11, UFR Medecine, Villejuif FRANCE

${ }^{6}$ INSERM Unit UMS-33, bioinformatics plateform, Villejuif FRANCE

${ }^{7}$ Institut Mondor de Recherche Biomédicale, INSERM U955-E10, Créteil, France,

${ }^{8}$ Université Paris Est, Faculté de Medecine, Créteil, France

9 AP-HP, Hôpital St Antoine/Trousseau, Service d'Hématologie Biologique, F- 75012 Paris, France.

${ }^{10}$ Sorbonne Universités, UPMC Univ Paris 06, CNRS UMR7622, Inserm U 1156, IBPS, Laboratoire de Biologie du Développement; 75005 Paris

*Correspondence to: thierry.jaffredo@upmc.fr; alain.chapel@irsn.fr 


\section{Introductory paragraph:}

The successful production of Hematopoietic Stem and Progenitor Cells (HSPCs) from human pluripotent sources is conditioned by transgene delivery ${ }^{1-5}$. We describe here a dedicated and tractable one step, GMP-grade, transgene-free and stroma-free protocol to produce HSPCs from human induced pluripotent stem cells (hiPSCs). This procedure, applied to several sources of hiPSCs with equal efficiency, is based on a directed differentiation with morphogens and cytokines to generate a cell population close to nascent HSPCs or their immediate forerunners i.e., hemogenic endothelial cells $^{6-9}$. Following engraftment into immunocompromised recipients, this cell population was proved capable of a robust myeloid, lymphoid and definitive red blood cell production in sequential recipients for at least 40 weeks. Further identification of the repopulating cells show that they express the G protein-coupled receptor APELIN (APLNR) and the homing receptor CXCR4. This demonstrates that the generation of bona fide HSPCs from hiPSCs without transgenes is possible and passes through an early endo-hematopoietic intermediate. This work opens the way to the generation of clinical grade HSPCs for the treatment of hematological diseases and holds promise for the analysis of HSPC development in the human species. 
While in standard hiPSC differentiation protocols, CD $34^{+} \mathrm{CD} 45^{+}$hematopoietic cells appeared from bursting Embryoid Bodies (EBs) at day 10 until day 14,5,10,11, here D17 EBs remained compact and spherical without burst therefore assessing a dramatic delay in differentiation (Fig. 1a). These culture conditions, reproducibly applied to three individual hiPSC lines, derived using different reprogramming protocols demonstrated the robustness of the method.

To determine the point of hemogenic endothelial cell (EC)/early HSPC commitment, we analyzed EBs by qRT-PCR on D3, 7, 9, 13, 15, 16 and 17 for the expression of 49 endothelialand hematopoietic-specific genes, with $\mathrm{CD}^{+} 4^{+}$cord blood $(\mathrm{CB})$ HSPCs as a reference (Supplementary Table 1). Hierarchical clustering (Fig. 1b, and Supplementary Fig. 1) revealed two main groups, one associated with $\mathrm{CD} 34^{+} \mathrm{CB}$ HSPCs and another one with D3 to D17 EBs. The latter displayed two distinct clusters: the early EBs (D3 to D13) and the late EBs (D15 to D17). Further analysis of the qRT-PCR identified D13 as the point of EC commitment based on CD309 (VEGFR2/FLK1) mRNA expression and D16 as hemogenic endothelial commitment/EHT based on RUNX1 mRNA expression (Fig. 1c) in keeping with developmental studies $^{12}$. Early HSPC commitment was overt from D17 testified by the expression of ITGA2 (Integrin alpha-2), CEBPA (CCAAT enhancer binding protein alpha), the transcription factors cMYB and SCL, this latter exhibiting a bimodal curve in keeping with its role on hemangioblast and hematopoietic commitment respectively ${ }^{13}$, the TPO receptor MPL (Fig 1c). Flow cytometry indicated a decrease in CD309 (EC marker) expression from D13 to D17 and an increase of ITGA2, CKIT and MPL (early HSPC markers) expressions (Fig. 1d) in keeping with the qRTPCR analysis (Fig. 1c).

We next evaluated the endothelial and hematopoietic potential of D15 to D17 EBs using dedicated ex vivo functional tests (Fig. 2a and Supplementary Table 2). D15 EBs displayed a 
strong endothelial-forming potential since they generate endothelial colony-forming cells (CFCs) (Fig. 2a1), pseudo-microtubules (Fig. 2a2) and endothelial-like cells (Fig. 2a3) ${ }^{14}$, but lacked hematopoietic-forming capacity, being unable to generate clonogenic colonies and displaying a low frequency of long term culture-initiating cells (Supplementary Table 2). In contrast D17 EBs lacked endothelial potential but showed an increased hematopoietic capacity (Fig. 2a4, a5), confirming hematopoietic commitment within this period.

D16 cells were probed in vivo by subcutaneous transplantation in Matrigel (growth factor reduced) plug with or without human Mesenchymal Stem Cells (hMSCs) into immunocompromised Foxn1 $1^{-/-}$(nude) mice (Fig. 2b) ${ }^{15}$. Two weeks after transplantation, both human vascular and hematopoietic differentiation was found. Human vascular structures (Fig. 2c, d, e), made of human von Willebrand factor ${ }^{+}$(Fig. 2d) and $\mathrm{CD}^{+} 1^{+}$(Fig. 2e) cells were detected in the graft seeded with D16 cells associated with (/) hMSCs. qRT-PCR revealed the expression of hVEGFR2, hENG (ENDOGLIN), hPECAM and hVE-CADHERIN in the D16 cells/hMSCs grafts and, as expected, in the endothelial progenitor cells/hMSCs grafts (Supplementary Fig. 2). Moreover, D16 cells/hMSCs grafts also expressed the CD45 antigen and human beta, gamma and epsilon globin transcripts, while D16 cell grafts alone expressed only human epsilon globin transcript disclosing a block of maturation (Supplementary Fig. 2). D16 EBs thus displayed a balanced endothelial-hematopoietic pattern in keeping with our ex vivo results.

Based on the newly-formed hematopoietic capability disclosed at D17, we transplanted $4 \times 10^{5}$ D17 cells intravenously into 30 sublethally irradiated (3.5 gray) 8-week-old immunocompromised mice for 20 weeks followed by a challenging secondary transplantation in similarly-treated immunocompromised recipients for 20 additional weeks and compared it 
systematically to $\mathrm{CD}^{+} 4^{+} \mathrm{CB}$ HSPCs (Fig. 3a, Supplementary Fig. 3a). Hematopoietic reconstitution quantified by the surface expression of hCD45, hCD43 and hCD34 (Fig. 3b and Supplementary Fig. $3 b-1)^{16}$ was evident in $30 / 30$ primary recipients and quantitatively comparable to that of CD $34^{+}$CB HSPCs (Fig. 3c and Supplementary Fig. 3b, c-e, j) with 20.3+/$2.9 \%$ of hCD $45^{+}$cells in total mouse BM mononucleated cells, i.e., more than 200 times the threshold of $0.1 \%$ usually considered as positive for human hematopoietic engraftment in NSG mice $^{17}$, and $12.2+/-1.5 \%$ of hCD $43^{+}$and $7.29+/-1.0 \%$ of hCD $34^{+}$. hCD $45^{+} \mathrm{BM}$ cells harbor several hematopoietic lineages including $\mathrm{B}$ and $\mathrm{T}$ lymphoid (hCD $19^{+}$and $\mathrm{hCD}^{+}$respectively) and myeloid (hCD14 $4^{+}$(Supplementary Fig. 4a-d) whereas hCD45 ${ }^{-}$BM cells harbor hCD235a ${ }^{+}$ erythroid progenitors/precursors (Supplementary Fig. 4a-b, e-f). Sorted hCD $45^{+}$blood cells displayed the same multilineage pattern (Supplementary Fig. 5a) indicating a peripheralization of the grafted cells comparable to results obtained with $\mathrm{CD} 34^{+} \mathrm{CB}$ HSPCs. Their human origin was confirmed $(n=30 / 30)$ by qRT-PCR using human-specific primers (Supplementary Fig. 4g, ). A human-specific clonogenic hematopoietic assay on BM cells from the first recipient revealed an overall frequency of $17.5+/-4.3$ clones out of $10^{4}$ total BM cells (Fig. 3f) distributed into CFUGEMM, BFU-E and CFU-GM colonies (Fig. 3g1, 2, 3) Cytospin analysis revealed mature macrophages, histiomonocytes, myelocytes and erythroblasts (Fig. 3h1, 2, 3). 7.10 6 BM cells from the primary recipient were challenged in a secondary $(n=30)$ (Fig 3d, e and Supplementary Fig. 3f-i, k) and eventually a tertiary $(n=3)$ recipient (Supplementary Fig. 31). Human CD45 cells represented $12.6+/-3.9 \%$ of the mononucleated BM cells at 20 weeks (Fig. 3d), indicating a sustained reconstitution capacity. Multilineage engraftment was found in 30/30 secondary mice (Fig. 3e, Supplementary Fig. 6a-e) and was comparable to the pattern obtained on secondary CD34 ${ }^{+}$CB HSPCs transplants (Supplementary Fig. 3f-i, k and Supplementary Fig. 6). The 
human CFCs cloning efficiency was 5.5+/-3.1\% in $10^{4}$ total mouse BM cells, pointing to a robust and prolonged self-renewal potential (Fig. 3f-h). The human origin of the engrafted cells was confirmed as above (Supplementary Fig. 3g).

To ensure the functionality of the grafted cells, we analyzed the ability of the human erythroid precursors from mouse BM to undergo hemoglobin switching in vivo and tested the phenotype and the functionality of $\mathrm{T}$ cells. Cells from both primary and secondary recipients generated human erythroid progenitors displaying high amounts of $\beta$ (respectively $39.51+/$ $4.95 \%$ and $36.61+/-5.86 \%$ ) and $\gamma$ globin (respectively $57.49+/-3.95 \%$ and $61.39+/-4.86 \%$ ) while $\varepsilon$ globin was dramatically reduced to respectively $3.0+/-1.2 \%$ and $2.1+/-1.1 \%$ of total globin (Fig. 3i), a hallmark of definitive erythrocytes. Peripheral blood hCD3 ${ }^{+} \mathrm{T}$ cells displayed high amounts of TCR $\alpha \beta$ (Fig. 3j) and low amounts of TCR $\gamma \delta$ similar to thymic hCD3 ${ }^{+}$cells (Supplementary Fig. 5b) reminiscent of normal $\mathrm{T}$ lymphopoiesis. B and $\mathrm{T}$ lymphopoiesis was revealed in spleen $\mathrm{CD} 45^{+}$cells by the expression of TCRß and hCD19 and were found similar to CD $34^{+}$CB HSPCs grafts (Supplementary Fig 5b). Thymus hCD3 ${ }^{+} \mathrm{T}$ cells, tested on their ability to expand ex vivo, measured by CSFE-labeling, under hCD3 and hCD28 stimulation (Fig. 3k) displayed a high expansion capacity after 5 days, thereby demonstrating $\mathrm{T}$ cells functionality.

To further identify the reconstituting population, we focused on APLNR related to ECs ${ }^{18}$ and HCs from human embryonic stem cells ${ }^{19}$ and to the homing receptor CXCR4 ${ }^{20,21}$. Differentiating EBs displayed an enhanced APLNR and CXCR4 expression from D7 to D17 with the emergence of a double stained population accounting for $32.1 \%$ of the cells at D17 (Fig 4a). Grafting efficiency at 20 weeks was directly proportional to the number of APLNR $^{+}$cells (Fig 4b). Moreover, only APLNR ${ }^{+}$cells reconstituted hematopoiesis after 20 weeks with 6.6+/$1.9 \%$ hCD $45^{+}$mononucleated cells, $3.4+/-2.5 \% \mathrm{hCD} 3^{+}$and $1.1+/-0.4 \% \mathrm{hCD} 34^{+}$in $6 / 6$ grafted 
mice (Fig. 4c, Supplementary Fig. 7a) and displayed multilineage reconstitution (Supplementary Fig. 7b-c), Importantly, D17 $\mathrm{APLNR}^{+}$cells did not harbor any CD45 cell indicating that reconstitution was not harbored by $\mathrm{hCD} 45^{+}$progenitors (Supplementary Fig. 7d). In contrast, APLNR $^{-}$cells failed to significantly engraft in $4 / 4$ mice with $0.08+/-0.01 \% \mathrm{hCD}^{+} 5^{+}$cells in mouse BM (Figure 4c, Supplementary Fig 7a). The APLNR ${ }^{+}$fraction also exhibited a homogeneous population of $\mathrm{ENG}^{+} / \mathrm{TIE}^{+} / \mathrm{CKIT}^{+}$(Fig. 4d) described to enhance definitive hematopoiesis in mice ${ }^{22}$. We compared the molecular profiles of APLNR ${ }^{+}$and APLNR ${ }^{-}$cells to that of D15 and D17 EBs, to hiPSCs and to control CD34 ${ }^{+}$CB HSPCs through the expression of the set of 49 genes (Supplementary Table 3). Principal component analysis (PCA) of the 49 mRNAs as variables and the six cell populations as observations revealed that the first component likely corresponded to the factor "hematopoietic differentiation" (44.9\% of the variance) (Fig. 4e). Aiming to reveal the traits involved in the grafting potential, we compared by PCA the APLNR ${ }^{+}, \mathrm{D} 17$ and CB HSPC populations to the APLNR ${ }^{-}$and hiPSC populations. The third component that accounted for $19.23 \%$ of the variance segregated two groups differing by their grafting potential (Fig. 4f). A statistical SAM test which measures the strength of the relationship between gene expression and a response variable pointed out 8 genes $(\mathrm{FDR}<10 \%)$ significantly up-regulated in the group unable to graft, among them endothelial genes as TEK, PECAM, and KDR (Fig. 4g).

Collectively, we show that the generation of long-term multipotent HSPCs supporting hematopoietic reconstitution and self-renewal in vivo, passes through an early differentiated cell expressing APLNR more likely an endothelial cell undergoing EHT or a newly formed HSPC. Since this study has been performed under GMP-grade conditions, it may be envisioned that pluripotent stem cells may become a prioritized source of cells for HSPC transplantation. 


\section{Figure Legends}

Fig. 1: Phenotypic characterization of hiPSC-derived endo-hematopoietic differentiation $e x$ vivo.

(a) Experimental scheme. HiPSCs were differentiated into EBs over 17 days with the continuous presence of growth factors and cytokines. EBs were characterized at different time points using q-PCR and flow cytometry. Images depicted representative EBs at D13 and 17 respectively.

(b) Hierarchical clustering summarizing the expression of the set of 49 genes characteristics of the endothelium, hemogenic endothelium and hematopoietic cells with time in D3, D7, D9, D13, D15 and D17 EBs and in CB CD34 ${ }^{+}$HSPCs.

(c) Q-PCR patterns of genes representative of the EHT balance from D13 to D17 EB differentiation. For each gene, the fold change is the mean $+/-$ SEM of 6 experiments

(d) Flow cytometry analysis of human CD309, ITGA2, MPL and CKIT expression at D13 and D17 of EB culture.

\section{Fig. 2: Functional endothelio-hematopoietic profiling between D15 and D17.}

(a) Ex vivo tests probing the presence of endothelial (1-3) and hematopoietic (4-5) progenitors in EBs with time. Dissociated D15-17 EBs generate (1) CFC-ECs, (2) pseudomicrotubules, (3) EC-like cells capable of several passages, (4) CFC, and (5) LTC-ICs.

(b) Experimental scheme for in vivo tests to probe the endothelial capacity of D16 cells.

(c) D16 cells/hMSCs plug section. Masson's trichrome staining.

(d) D16 cells/hMSCs plug section. Human von Willebrand factor ${ }^{+}$cells (blue) immunostaining.

(e) D16 cells/hMSCs plug section. Human $\mathrm{CD}^{+} 1^{+}$immunostaining (red). Cell nuclei are counterstained by DAPI.

Fig. 3: In vivo engraftment of D17 EBs in immunocompromised mice. 
(a) Experimental design.

(b) Representative flow cytometry analysis of human vs mouse CD45 ${ }^{+}$cell engraftment in a BM primary recipient.

(c-d) Engraftment of hCD $34^{+} \mathrm{hCD} 43^{+}$and hCD $45^{+} \mathrm{HSPCs}$ in primary (c) or secondary (d) mouse BM 20 weeks post graft. Data are the mean +/- SEM.

(e) Human hematopoietic lineage distribution in representative secondary recipients. Cells were gated on $\mathrm{hCD}^{+} 5^{+}$expression for $\mathrm{hCD} 33$, hCD19 and hCD3 whereas hCD235a was analyzed on whole BM cells. Data are the mean +/- SEM.

(f) Clonogenic hematopoietic tests on BM cells isolated from primary and secondary recipients. Frequency of CFU-GM, BFU-E and CFU-GEMM colonies.

(g) Representative colonies of CFU-GEMM (1), BFU-E (2) and CFU-GM (3) from primary and secondary BM cells.

(h) Cytospins. May Grünwald-Giemsa staining of cells isolated from clonogenic tests performed on primary and secondary recipients. Mature macrophages (1), histiomonocytes (2), myelocytes (2) and erythroblasts (3).

(i) Human globin expression from $\mathrm{CB} \mathrm{CD} 34^{+} \mathrm{HSPCs}$ erythroid culture, from BM primary and secondary recipients and BFU-E from BM primary recipients. Data are mean +/- SEM.

(j) Maturation of human T cells. Peripheral blood stained with antibodies against hTCR $\alpha \beta$ and hTCR $\gamma \delta$, the cells are first gated on hCD3 and analyzed for TCR expression.

(k) Functionality of human T cells. The whole thymus population is CFSE labeled at D0 and gated on $\mathrm{hCD}^{+}$expression (green). At D5, the unstimulated population is red while the stimulated parent population is blue.

Figure 4: Functional and molecular characterization of the APLNR ${ }^{+}$population.

(a) Flow cytometry analysis of APLNR and CXCR4 expression from D7 to D17 EB culture.

(b) Correlation between the percentage of $\mathrm{APLNR}^{+}$cells in the graft to those of hCD $45^{+}$cells in the NOD-SCID BM primary recipients, 18weeks post-graft. 
(c) Engraftment capacities of the $\operatorname{APNLR}^{+}\left(n=6\right.$, red dots) and $\operatorname{APNLR}^{-}(n=4$, grey triangles) populations. Cells containing the reconstitution potential are within the APLNR ${ }^{+}$population. Data are expressed as the mean +/- SEM percentages of human engraftment, 18 weeks after transplant.

(d) Combinatorial flow cytometry analysis of the APLNR $^{+}$population using CD45, TIE, ENG and CKIT anti-human antibodies.

(e) PCA with the set of 49 mRNAs as variables and the six cell populations as observations. PC1 versus PC2 score plot. The PC1 dimension likely corresponds to the trait « hematopoietic differentiation» which accounts for $44.9 \%$ of the variance. HiPSCs are segregated from the other populations on the second component which accounts for $24 \%$ of the variance.

(f) PCA with the set of 49 mRNAs as variables and the populations endowed or not with grafting potential. The PC3 dimension which accounts for $19.23 \%$ of the variance segregates the two groups.

(g) Heat map of the genes permitting the segregation of the two groups in (f). 


\section{Materials and Methods:}

\section{hiPSC amplification}

The study was conducted using three different hiPSC lines: the FD136-25 (skin primary fibroblasts), reprogrammed with retroviral vectors and Thomson's combination (endogenous expression of Oct4, Sox2, Nanog and Lin28); the Pci-1426 and Pci-1432 lines (peripheral blood mononuclear cells-Phenocell) reprogrammed with episomes (Sox2, Oct4, KLF, cMyc). hiPSCs were maintained on CellStart (Invitrogen, Carlsbad, USA) in TESR2 medium (Stem Cell Technologies, Bergisch Gladbach, Germany) and the cells were passaged 1:6 onto freshly coated plates every 5 days using standard clump passaging with TRYple select (Invitrogen).

\section{EB differentiation}

EB differentiation was induced as previously described. After $24 \mathrm{~h}$, cells were transferred into differentiation medium (Lapillonne et al., 2010) containing $22 \mathrm{ng} / \mathrm{mL}$ of SCF, $20 \mathrm{ng} / \mathrm{mL}$ of TPO, $300 \mathrm{ng} / \mathrm{mL}$ of FLT3, $22 \mathrm{ng} / \mathrm{mL}$ of BMP4, $200 \mathrm{ng} / \mathrm{mL}$ of VEGF, $50 \mathrm{ng} / \mathrm{mL}$ of IL3, $50 \mathrm{ng} / \mathrm{mL}$ of IL6, $5 \mathrm{ng} / \mathrm{mL}$ of IL1, $100 \mathrm{ng} / \mathrm{mL}$ of GCSF, $50 \mathrm{ng} / \mathrm{mL}$ of IGF1 (PeproTech, Neuilly-sur-Seine, France). Medium was changed every other day.

\section{Colony assays}

At the indicated times, $1 \times 10^{5}$ dissociated EBs or $3 \times 10^{4}$ cells from xenotransplanted recipient BM were plated into $3 \mathrm{~mL}$ of complete methylcellulose medium in the presence of SCF, IL-3, EPO and GM-CSF (PeproTech, Neuilly-sur-Seine, France). As G-CSF also stimulates mouse progenitors, it was replaced by granulocyte-macrophage colony-stimulating factor (GM-CSF). 
Aliquots $(1 \mathrm{~mL})$ of the mix were distributed into one $30 \mathrm{~mm}$ dish twice and maintained in a humidified chamber for 14 days. Colony-forming Cells (CFC) were scored on day 14.

\section{Long-term culture-initiating cell assays}

Long-term culture-initiating cell (LTC-IC) assays were performed as described previously (35), 15-100,000 cells/well on day 17 for the EBs and on day 0 for the control CD34+. Absolute LTCIC counts corresponded to the cell concentrations, yielding 37\% negative wells using Poisson statistics.

\section{Pseudo-microtubules and EPC-like cells}

For Pseudo-microtubules formation, cells were transferred onto growth factor reduced Matrigel (Corning) and culture in EGM2 medium (Lonza).

For EPC-like cells generation, cells were first plated on gelatin and cultured in EBM2 (Lonza) and split several times, after the first passaged the gelatin was no longer mandatory.

\section{Flow cytometry}

Staining of BM cells or dissociated EBs was performed with $2 \times 10^{5}$ cells in $100 \mu \mathrm{L}$ staining buffer (PBS containing 2\% FBS) with 5:100 dilution of each antibody, for 20 min at room temperature in the dark. Data acquisition was performed on a Becton Dickinson Canto II cytometer. 


\section{In vivo analyses of angiogenesis potential}

Foxn1-/- nude mice (Charles River, L'Abresle, France) were housed in the IMRB animal care facility. All experiments and procedures were performed in compliance with the French Ministry of Agriculture regulations for animal experimentation and approved by the local ethics committee.

In vivo assessment of the endothelial and hematopoietic potentials were probed on 9 nude mice.

$1.75010^{6} \mathrm{D} 16$ single cells or hEPCs and $1.75010^{6} \mathrm{hMSC}$ were mixed with $100 \mu \mathrm{l}$ of Matrigel phenol red free and growth factor reduced (Corning) and subcutaneously injected into the back of nude mice (two different plugs/ mouse). The controls were performed similarly but with 3.5 $10^{6} \mathrm{hMSCs}$ or D16 single cells or hEPCs; for each condition $\mathrm{n}=3$. Two weeks later, mice were sacrificed, the matrigel plug dissected out and cut into two parts. One part was processed for paraffin sectioning. Sections were deparaffinized, hydrated and stained whether with Masson's trichrome, a three-color protocol comprising nuclear staining with hematoxylin, cytoplasmic staining with acid fuchsin/xykidine ponceau and collagen staining with Light Green SF (all from VWR); or whether with an anti human Von Willebrand factor antibody (Dako), staining was developed with histogreen substrate (Abcys) and counterstained with Fast nuclear red (DakoCytomation), dehydrated and mounted, or wether with hCD31 (R\&D system) as primary antibody and donkey anti-rabbit Cy3 (Jackson ImmunoResearch) as secondary antibody and DAPI and mounted with fluoromount G.

\section{Sorting of APLNR positive cells}


Cells were stained with the antibody hAPJ-APC clone 72133 (R\&D systems) as described above.

Sorting was carried out on a Moflo ASTRIOS Beckman Coulter apparatus and the purity was 98.1\% $\mathrm{APLNR}^{+}$cells.

\section{Mouse transplantation}

NOD/SCID-LtSz-scid/scid (NOD/SCID) and NOD.Cg-Prkdc ${ }^{\text {scid }}$ Il2 $^{\text {rg }}{ }^{\text {tm1Wjl }} / \mathrm{SzJ}$ (NSG) (Charles

River, L'Abresle, France) were housed in the IRSN animal care facility. All experiments and procedures were performed in compliance with the French Ministry of Agriculture regulations for animal experimentation and approved by the local ethics committee.

Mice, 6-8 weeks old and raised under sterile conditions, were sublethally irradiated with 3.5 Grays from a $137 \mathrm{Cs}$ source $(2.115 \mathrm{~Gy} / \mathrm{min}) 24 \mathrm{~h}$ before cell injection. To ensure consistency between experiments, only male mice were used. Prior to transplantation, the mice were temporarily sedated with an intraperitoneal injection of ketamine and xylazine. Cells $\left(4 \times 10^{5}\right.$ per mouse) were transplanted by retro-orbital injection in a volume of $100 \mu \mathrm{L}$ using a 28.5 gauge insulin needle. A total of 147 mice were used in this study.

For the engraftment potential of the D17 cells on the three different hiPSC lines:

86 NSG mice were used as followed: 30 primary recipients, 30 secondary recipients and 26 as control.

48 NOD-SCID mice were used as followed: 20 primary recipients and 16 secondary recipients, 3 tertiary recipients and 9 as control.

For the engraftment potential of $\mathrm{APLNR}^{+}$and $\mathrm{APLNR}^{-}$population: 10 NOD-SCID mice were used and 3 NOD-SCID as control. 


\section{Assessment of human cell engraftment}

Mice were sacrificed at week 12,18 or 20 . Femurs, tibias, liver, spleen and thymus were removed. Single cell suspensions were prepared by standard flushing and aliquots containing $1 \times 10^{6}$ cells were stained in a total volume of $200 \mu \mathrm{L}$ staining buffer.

Samples were stained for engraftment assessment with the following markers: hCD45 clone J33, hCD43 clone DFT1, hCD34 clone 581 (Beckman Coulter) and hCD45 clone 5B1, mCD45 clone 30F11 (Miltenyi)

The BM of three mice were pooled to allow hCD45 microbead enrichment (Miltenyi), the multilineage was assessed using the following human markers : hCD3 clone UCHT1, hCD4 clone 13B8.2, hCD8 clone B9.11, hCD14 clone RMO52, hCD15 clone 80H5, hCD19 clone J3119, hCD20 clone B9E9, hCD43 clone DFT1, hCD34-APC, hCD71 clone YDJ1.2.2 (all from Beckman Coulter antibodies, Brea, USA), CD45 clone 5B1 (Miltenyi), CD235a clone GA-R2 (Becton-Dickinson).

The blood samples of three mice were pooled to allow hCD45 microbead sorting (Miltenyi). The multilineage potential was assessed using the following human markers : hCD3 clone UCHT1, hCD4 clone 13B8.2, hCD8 clone B9.11, hCD14 clone RMO52, hCD15 clone 80H5, hCD11B Bear1, hCD19 clone J3-119, hCD20 clone B9E9, hIGM clone SA-DA4 (all from Beckman Coulter antibodies, Brea, USA).

Non-injected mouse BM was used as a control for non-specific staining.

Compensation was performed by the FMO method with anti-mouse Ig and data were acquired on a BD Canto II cytometer.

\section{T-cell maturity and functionality assay}


The presence of TCR $\alpha \beta$ and TCR $\gamma \delta$ in peripheral blood was assessed by flow cytometry using the following human markers : hCD3 clone UCHT1 (positive gating), TCR $\alpha \beta$ clone IP26A and TCR $\gamma \delta$ clone IMMU510 (all from Beckman Coulter antibodies, Brea, USA).

Thymus and spleen cells were isolated, CFSE labelled and seeded in cell culture media complemented or not with hCD3 and hCD28 (Beckman Coulter both $1 \mu \mathrm{g} / \mathrm{ml}$ ). After 5 days, cells were harvested and stained with anti-hCD3 clone UCHT1 and analyzed on a BD Canto II cytometer. FlowJo analysis software was used to gate on $\mathrm{CD} 3^{+}$T-cells and generate the overlaid histogram plots.

\section{Assessment of the APLNR cell safety}

Three sub-lethally irradiated NOD/SCID mice were subcutaneously injected each with 3 million APLNR positive cells. No teratoma was found after 2 months follow-up according to FDA guidelines.

In addition, no tumor was macroscopically detected in any mouse after analysis of the organs (140/140 mice) or after microscopic analysis of different tissues (brain, lungs, kidneys, BM, liver and gut) (140/140 mice).

\section{Quantitative PCR}

Total mRNA was isolated with the RNA minikit (Qiagen, Courtaboeuf, France). mRNA integrity was checked on a Bioanalyzer 2100 (Agilent Technologies, Massy, France). cDNAs were constructed by reverse transcription with Superscript (Life Technologies, Carlsbad, USA). PCR assays were performed using a TaqMan PCR master mix (Life Technologies) and specific primers (Applied BioSystems, Carlsbad, USA) for selected genes (see table below), together 
with a sequence detection system (QuantStudio ${ }^{\mathrm{TM}}$ 12K Flex Real-Time PCR System, Life Technologies). In each sample the fluorescent PCR signal of each target gene was normalized to the fluorescent signal of the housekeeping gene glyceraldehyde 3-phosphate dehydrogenase (GAPDH).

The human origin of the mRNAs from mouse BM was assessed by measuring hCD45, hCD15, hMPO, hITGA2 and hGAPDH. From CFCs post grafting and globin type expression in the mouse BM, we measured beta, gamma and epsilon globins using Taqman probes.

Controls were cultured erythroblasts generated from cord blood CD34 ${ }^{+}$.

\begin{tabular}{|c|c|c|c|c|c|c|}
\hline \multirow{6}{*}{$\begin{array}{l}\text { Pluripotency } \\
\text { genes }\end{array}$} & Hs01053049_s1 & SOX2 & \multirow{5}{*}{\multicolumn{2}{|c|}{ Endothelial genes }} & \multicolumn{2}{|c|}{ Hs00945146_m1 TEK } \\
\hline & \multicolumn{2}{|c|}{ Hs00153408_m1 MYC } & & & \multicolumn{2}{|c|}{\begin{tabular}{|l|l|} 
Hs00231079_m1 & RUNX1 \\
\end{tabular}} \\
\hline & Hs00702808_s1 & LIN28A & & & \multicolumn{2}{|c|}{ Hs00911700_m1 KDR } \\
\hline & Hs04260366_g1 & NANOG & & & \multirow[t]{2}{*}{ Hs01574659_m1 } & \multirow[t]{2}{*}{ NOS3 } \\
\hline & Hs00358836_m1 & KLF4 & & & & \\
\hline & Hs00742896_s1 & POU5F1 & \multirow{2}{*}{\multicolumn{2}{|c|}{ Human housekeeping genes }} & \multirow[t]{2}{*}{ Hs00357333_g1 } & \multirow{2}{*}{$\begin{array}{l}\text { Human beta } \\
\text { actin } \\
\text { Human } \\
\text { GAPDH }\end{array}$} \\
\hline \begin{tabular}{|l} 
Mouse \\
housekeeping \\
genes
\end{tabular} & Mm99999915_g1 & $\begin{array}{l}\text { Murine } \\
\text { GAPDH }\end{array}$ & & & & \\
\hline \multirow{17}{*}{$\begin{array}{l}\text { Hematopoietic } \\
\text { genes }\end{array}$} & Hs00924296_m1 & MPO & Hs01076122_m1 & DNTT & Hs00269972_s1 & CEBPA \\
\hline & Hs01106466_s1 & FUT4 & Hs00172743_m1 & RORC & Hs01115556 m1 & MITF \\
\hline & Hs00174029_m1 & cKIT & Hs00962186_m1 & CD3G & Hs01029175_m1 & NFIB \\
\hline & Hs01116228_m1 & ITGA2B & Hs00169777_m1 & PECAM & Hs04188695_m1 & HOPX \\
\hline & Hs00766613_m1 & APLNR & Hs00231119_m1 & GATA2 & Hs00171406_m1 & HLF \\
\hline & Hs00161700_m1 & STIL & Hs00959427_m1 & EPOR & Hs01070488_m1 & RBPMS \\
\hline & Hs00231119_m1 & GATA2 & Hs00610592_m1 & KLF1 & Hs00171569_m1 & HMGA2 \\
\hline & Hs00995536_m1 & BMI1 & Hs01085823_m1 & GATA1 & Hs00223161_m1 & PRDM16 \\
\hline & Hs00941830_m1 & NCAM1 & Hs04186042_m1 & RUNX1 & Hs01017441_m1 & MEIS1 \\
\hline & Hs04189704_m1 & PTPRC & Hs00176738_m1 & MATK & Hs00414553_g1 & NKX2-3 \\
\hline & Hs00174333_m1 & CD19 & Hs00180489_m1 & MPL & Hs00971097_m1 & MLLT3 \\
\hline & Hs00162150_m1 & SPIB & Hs04334142_m1 & FLI1 & Hs00925052_m1 & GATA3 \\
\hline & Hs00958474_m1 & IKZF1 & Hs00268388_s1 & SOX4 & Hs01128710_m1 & IRF8 \\
\hline & Hs01851142_s1 & RAG2 & Hs00193527_m1 & C-MYB & Hs00256884_m1 & HOXB4 \\
\hline & Hs00266821_m1 & HOXA9 & Hs01554629_m1 & ERG & Hs00610592_m1 & KLF1 \\
\hline & Hs00931969 m1 & RORA & Hs01547250 m1 & LEF1 & Hs04334142 m1 & FLI1 \\
\hline & Hs00959427 m1 & EPOR & Hs00176738 m1 & MATK & Hs00180489 m1 & MPL \\
\hline
\end{tabular}




\section{Statistical analysis}

All statistics were determined with R Software 3.1.1 (2014-07-10) (R Core Team, 2013),

INGENUITY and SAM Software. Data are represented with hierarchical clustering and PCA.

\section{References}

H. Lapillonne et al., Red blood cell generation from human induced pluripotent stem cells: perspectives for transfusion medicine. Haematologica. 95:1651-1659 (2010).

\section{Aknowledgments:}

We would like to thank Franck Chiappini for help in statistical analysis, Charles Durand for expert assistance with heat map and PCA analysis, Stéphane Viville for providing iPS line, Georges Tarlet, Christine Linard, Marianne Gervais-Taurel and Dhouha Darghouth for their technical support, Rima Haddad for her scientific support and Sophie Gournet for excellent drawing assistance. This work was supported by "Direction Générale de l'Armement" via the ASTRID/ANR program, the Etablissement Français du Sang (EFS) via the APR 2013 and the association "Combattre La Leucémie". These studies were supported by a joint grant from Agence Nationale pour la Recherche/California Institute for Regenerative Medicine (ANR/CIRM 0001-02) for TJ.

\section{Author contributions}

L.G.H. and L.D. designed the study, analyzed the data, and wrote the manuscript. A.C. designed the study. L.G.H. performed experiments with assistance of B.L., B.B. and N.C.; H.L., C.D. and 
L.G. helped to analyze the results; T.J. analyzed the data and wrote the manuscript. M.B. and

F.D. helped design the study; A.C. and L.D. supervised the study.

Competing financial interests:

L.G.H., C.D., T.J., L.G., L.D. and A.C. submitted a patent on the use of APLNR+ cell population to improve hematopoietic graft. 


\section{References}

1. Doulatov, S., et al. Induction of multipotential hematopoietic progenitors from human pluripotent stem cells via respecification of lineage-restricted precursors. Cell stem cell 13, 459-470 (2013).

2. Sandler, V.M., et al. Reprogramming human endothelial cells to haematopoietic cells requires vascular induction. Nature 511, 312-318 (2014).

3. Sugimura, R., et al. Haematopoietic stem and progenitor cells from human pluripotent stem cells. Nature 545, 432-438 (2017).

4. Lis, R., et al. Conversion of adult endothelium to immunocompetent haematopoietic stem cells. Nature 545, 439-445 (2017).

5. Risueno, R.M., et al. Inability of human induced pluripotent stem cell-hematopoietic derivatives to downregulate microRNAs in vivo reveals a block in xenograft hematopoietic regeneration. Stem cells $\mathbf{3 0}$, 131-139 (2012).

6. Swiers, G., Rode, C., Azzoni, E. \& de Bruijn, M.F. A short history of hemogenic endothelium. Blood cells, molecules \& diseases 51, 206-212 (2013).

7. Antas, V.I., A1-Drees, M.A., Prudence, A.J., Sugiyama, D. \& Fraser, S.T. Hemogenic endothelium: a vessel for blood production. Int J Biochem Cell Biol 45, 692-695 (2013).

8. Sturgeon, C.M., Ditadi, A., Clarke, R.L. \& Keller, G. Defining the path to hematopoietic stem cells. Nature biotechnology 31, 416-418 (2013).

9. Slukvin, II. Deciphering the hierarchy of angiohematopoietic progenitors from human pluripotent stem cells. Cell cycle 12, 720-727 (2013).

10. Lengerke, C., et al. Hematopoietic development from human induced pluripotent stem cells. Ann N Y Acad Sci 1176, 219-227 (2009).

11. Ditadi, A., et al. Human definitive haemogenic endothelium and arterial vascular endothelium represent distinct lineages. Nature cell biology 17, 580-591 (2015).

12. Yzaguirre, A.D., de Bruijn, M.F. \& Speck, N.A. The Role of Runx1 in Embryonic Blood Cell Formation. Advances in experimental medicine and biology 962, 47-64 (2017).

13. Van Handel, B., et al. Scl represses cardiomyogenesis in prospective hemogenic endothelium and endocardium. Cell 150, 590-605 (2012).

14. Smadja, D.M., Cornet, A., Emmerich, J., Aiach, M. \& Gaussem, P. Endothelial progenitor cells: characterization, in vitro expansion, and prospects for autologous cell therapy. Cell biology and toxicology 23, 223-239 (2007).

15. Duttenhoefer, F., et al. 3D scaffolds co-seeded with human endothelial progenitor and mesenchymal stem cells: evidence of prevascularisation within 7 days. European cells \& materials 26, 49-64; discussion 64-45 (2013).

16. Tourino, C., et al. Efficient ex vivo expansion of NOD/SCID-repopulating cells with lympho-myeloid potential in hematopoietic grafts of children with solid tumors. The hematology journal : the official journal of the European Haematology Association / EHA 2, 108-116 (2001).

17. Dick, J.E., Pflumio, F. \& Lapidot, T. Mouse models for human hematopoiesis. Semin Immunol 3, 367-378 (1991).

18. Kidoya, H., et al. Spatial and temporal role of the apelin/APJ system in the caliber size regulation of blood vessels during angiogenesis. The EMBO journal 27, 522-534 (2008).

19. Yu, Q.C., et al. APELIN promotes hematopoiesis from human embryonic stem cells. Blood 119, 62436254 (2012).

20. Peled, A., et al. Dependence of human stem cell engraftment and repopulation of NOD/SCID mice on CXCR4. Science 283, 845-848 (1999).

21. Kollet, O., et al. Human CD34(+)CXCR4(-) sorted cells harbor intracellular CXCR4, which can be functionally expressed and provide NOD/SCID repopulation. Blood 100, 2778-2786 (2002).

22. Nasrallah, R., et al. Endoglin potentiates nitric oxide synthesis to enhance definitive hematopoiesis. Biology open 4, 819-829 (2015). 
bioRxiv preprint doi: https://doi.org/10.1101/177691; this version posted August 21, 2017. The copyright holder for this preprint (which was not certified by peer review) is the author/funder. All rights reserved. No reuse allowed without permission.

EB differentiation

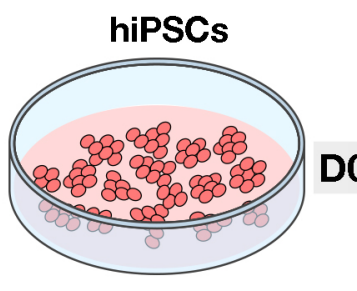

DO D3

+BMP4+VEGF+IGF1+SCF+FLT3+TPO+IL1, 3, 6+G-CSF

b

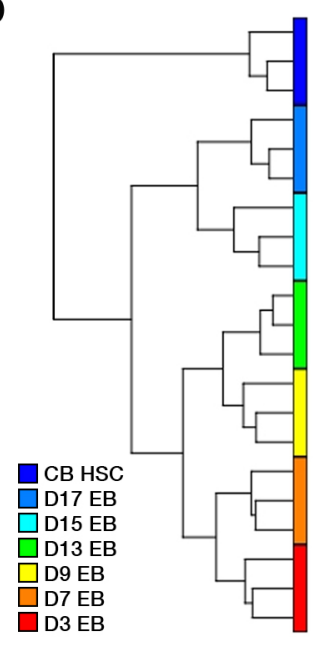

D7 D9 D13 Flow cytometry Gene expression
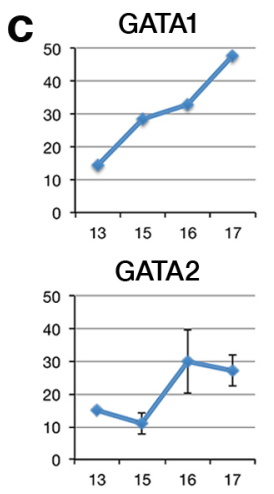

GATA3
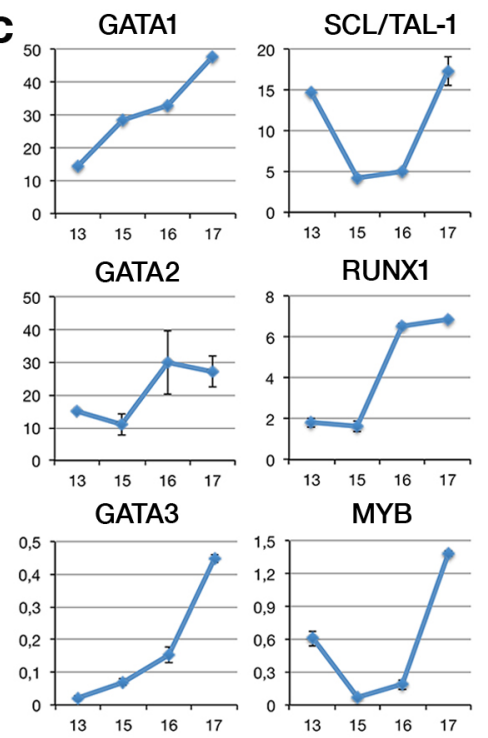

RUNX1

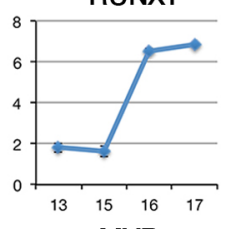

MYB
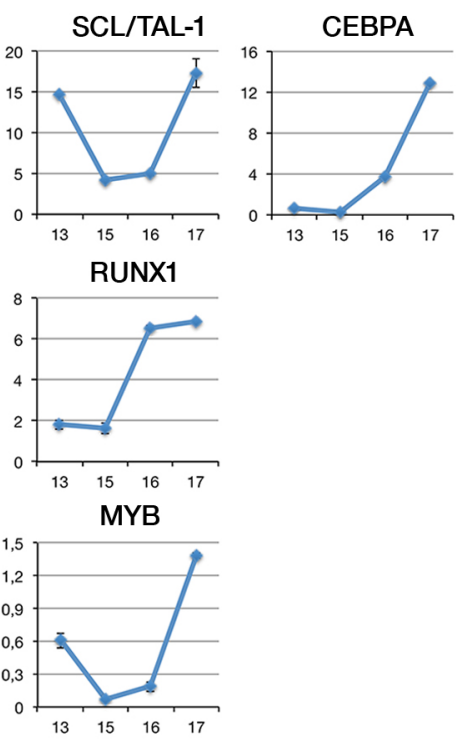

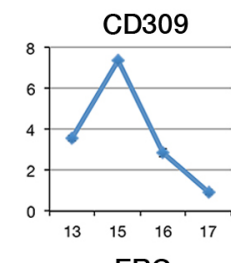

ERG

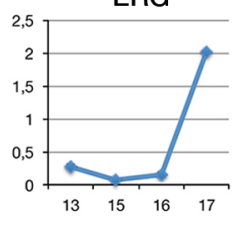

ITGA2

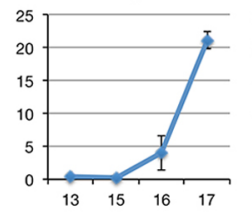

D13

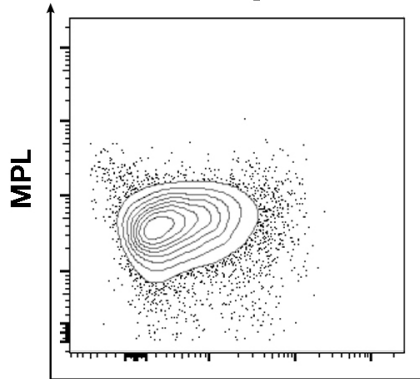

D17

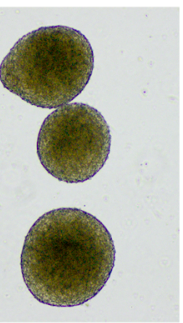

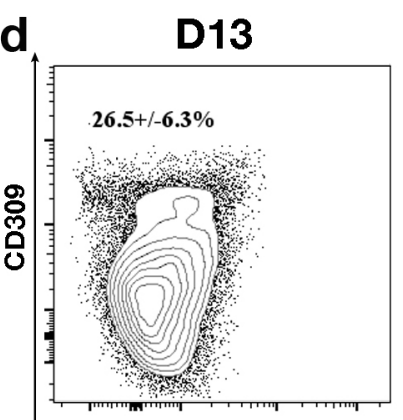

D17

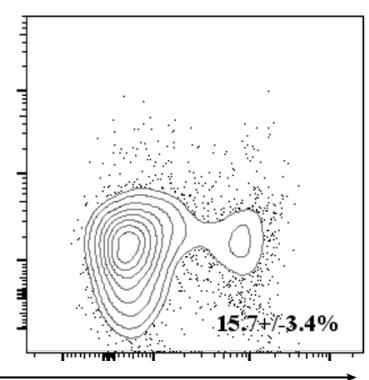

ITGA2

CKIT

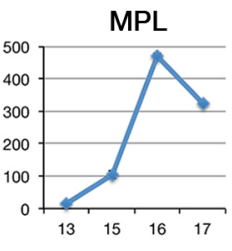

CD31
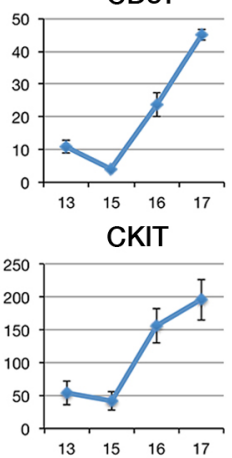

D17

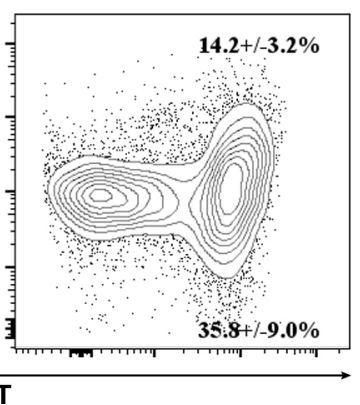


bioRxiv preprint doi: https://doi.org/10.1101/177691; this version posted August 21, 2017. The copyright holder for this preprint (which was not certified by peer review) is the author/funder. All rights reserved. No reuse allowed without permission.

a

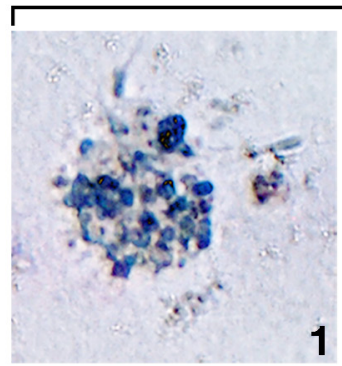

D15

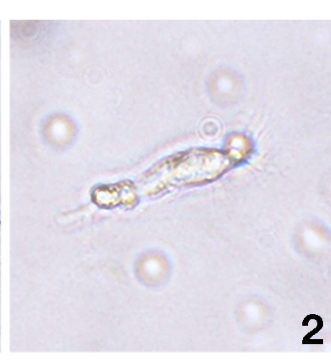

D17

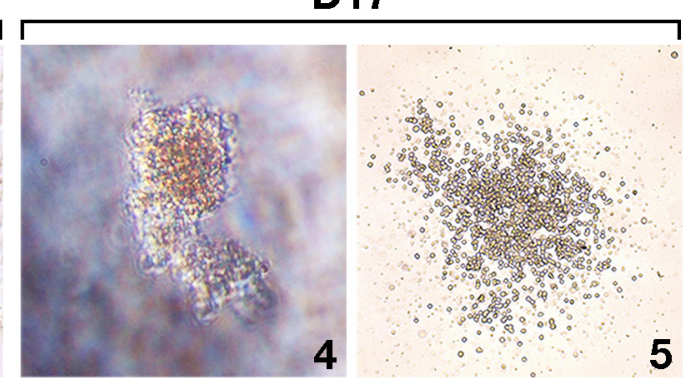

b
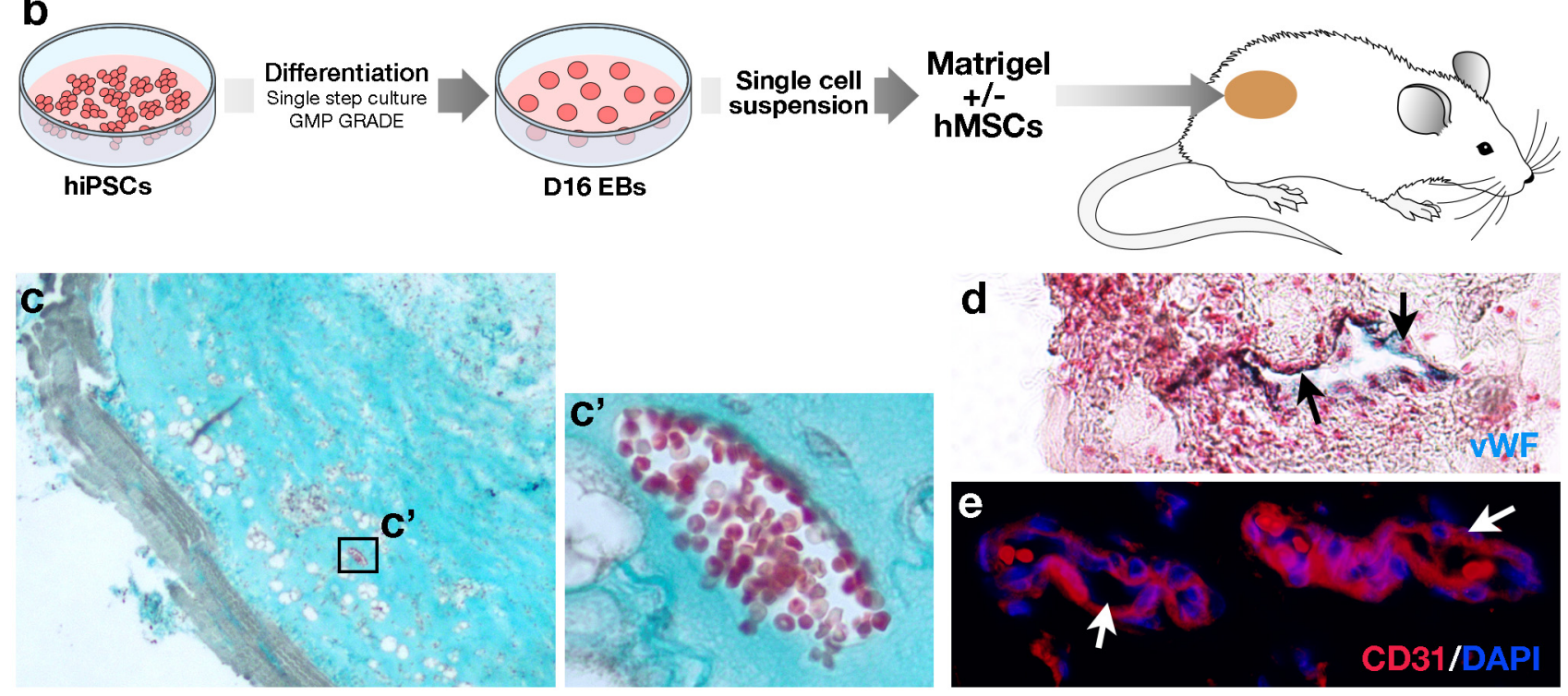

d

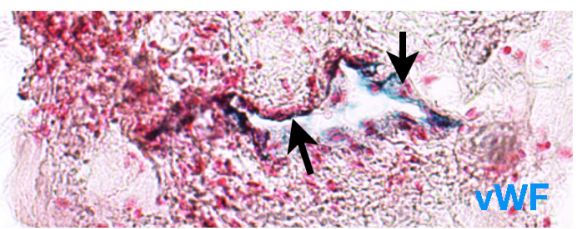

$\mathbf{e}$

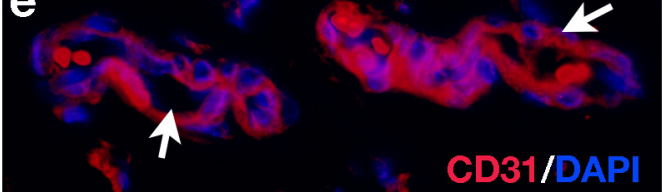


bioRxiv preprint doi: https://doi.org/10.1101/177691; this version posted August 21, 2017. The copyright holder for this preprint (which was not certified by peer review) is the author/funder. All rights reserved. No reuse allowed without permission.
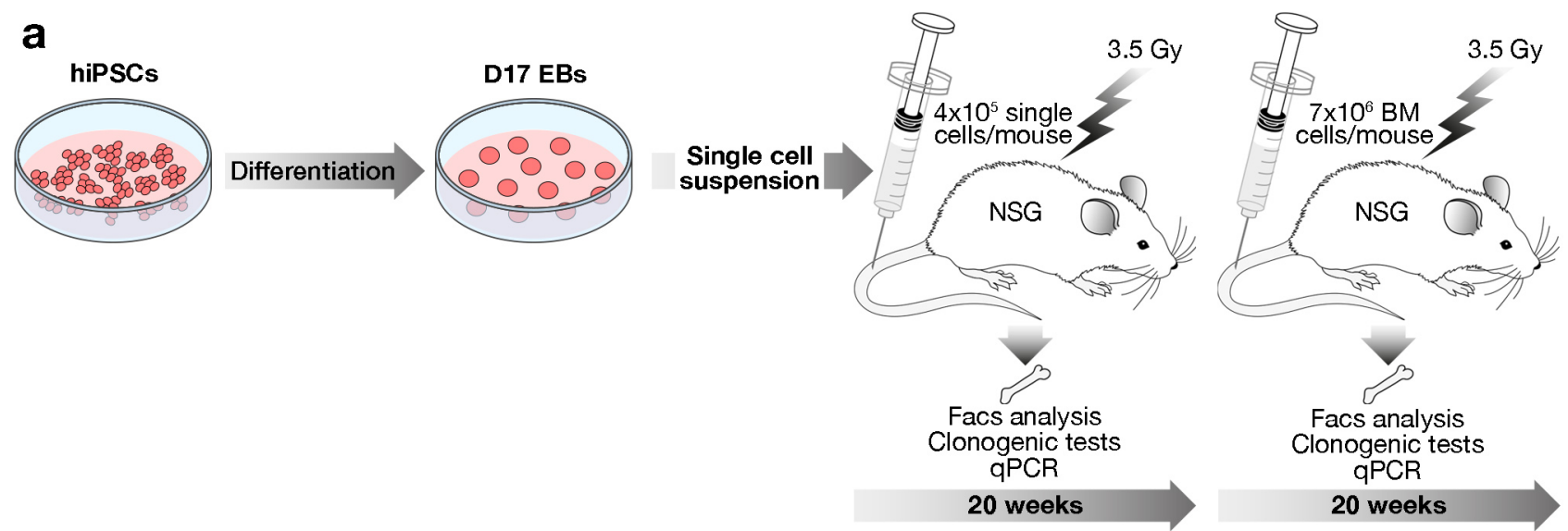

b

C

d

e

$\mathrm{I}^{\circ}$ transplant, $\mathrm{BM}, 20$ weeks

$\mathrm{II}^{\circ}$ transplant, $\mathrm{BM}, 20$ weeks $\quad \mathrm{HC}$ in $\mathrm{II}^{\circ}$ transplant, $\mathrm{BM}, 20$ weeks
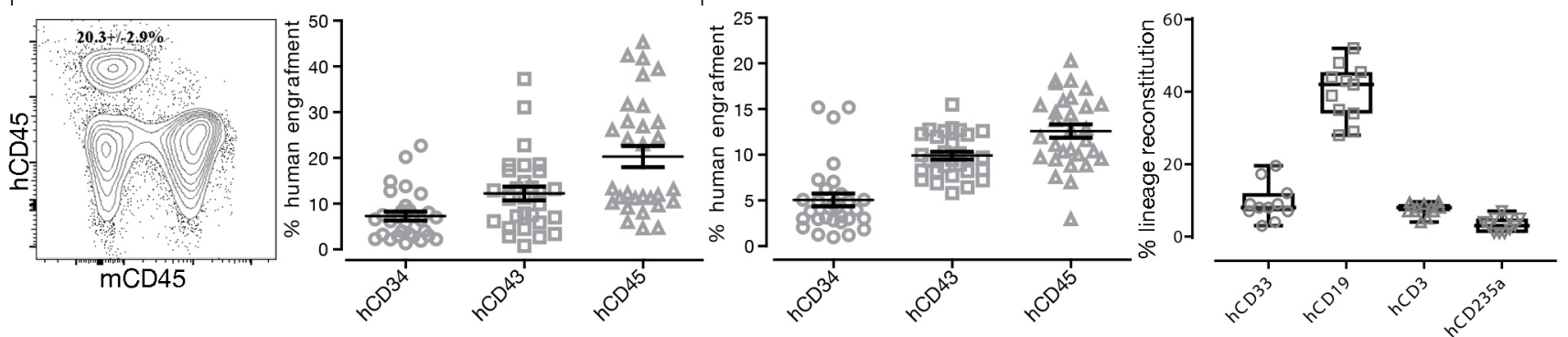

$\mathbf{f}$
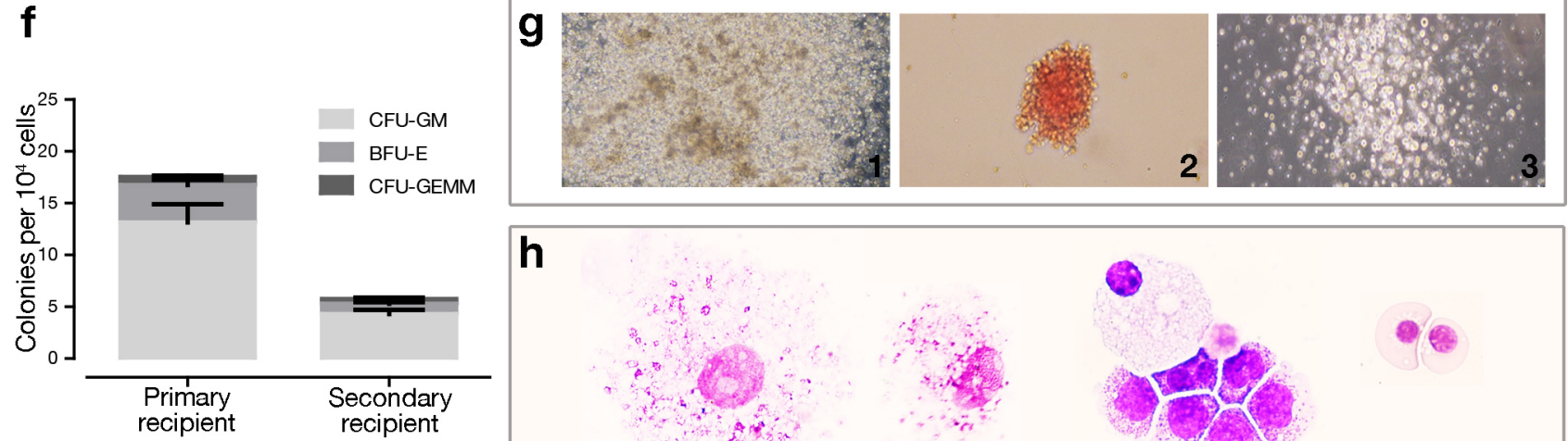

h
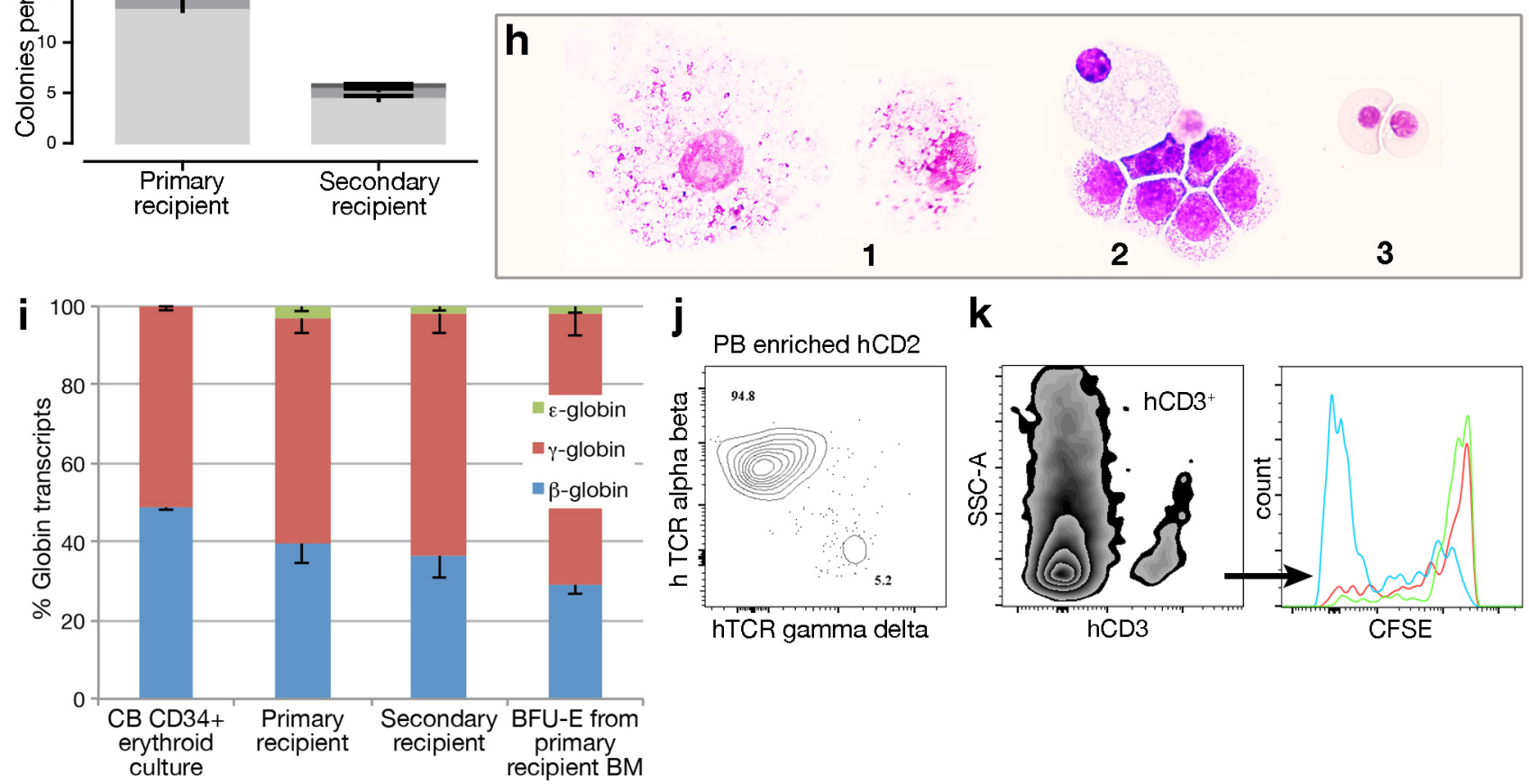

$\mathbf{k}$

PB enriched hCD2
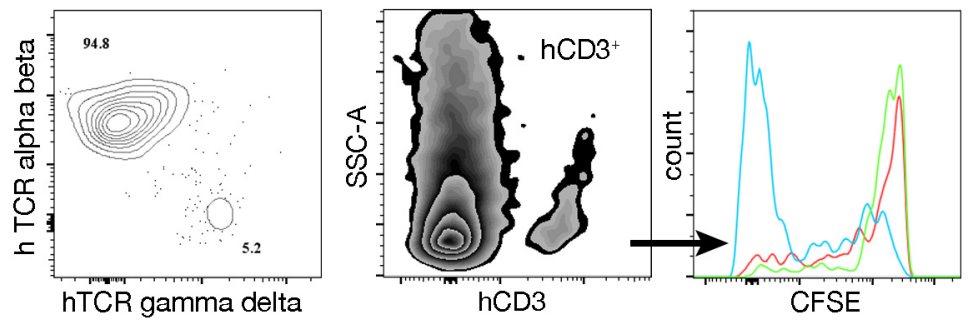
bioRxiv preprint doi: https://doi.org/10.1101/177691; this version posted August 21, 2017. The copyright holder for this preprint (which was not certified by peer review) is the author/funder. All rights reserved. No reuse allowed without permission.

a
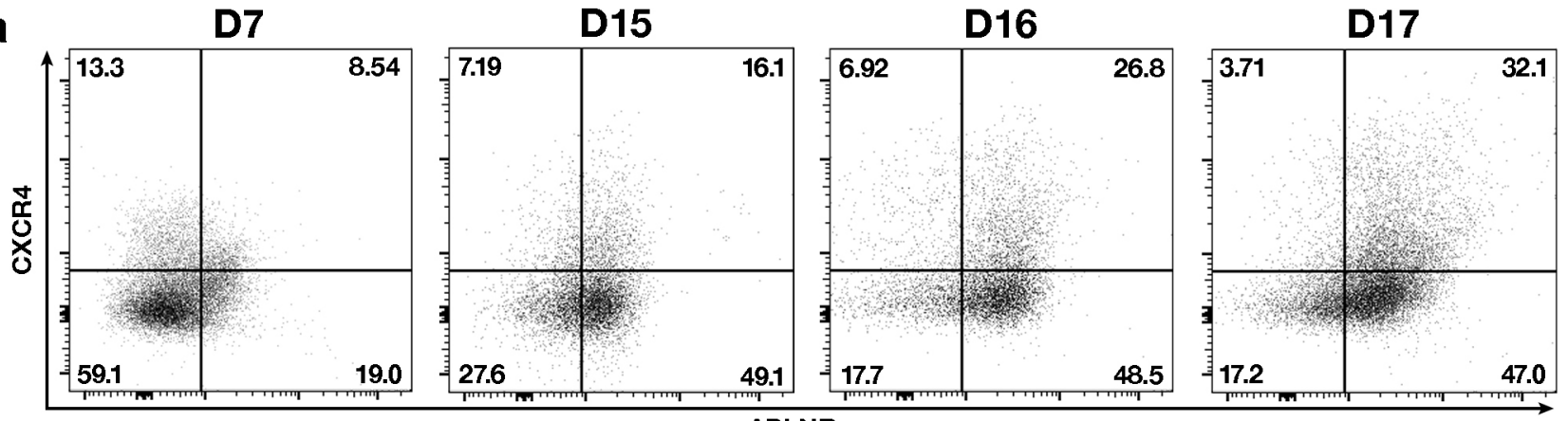

b

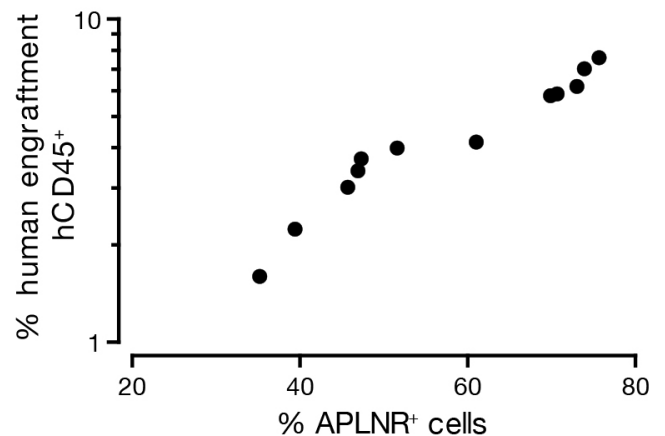

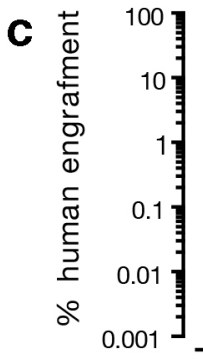

$\% \mathrm{APLNR}^{+}$cells

d
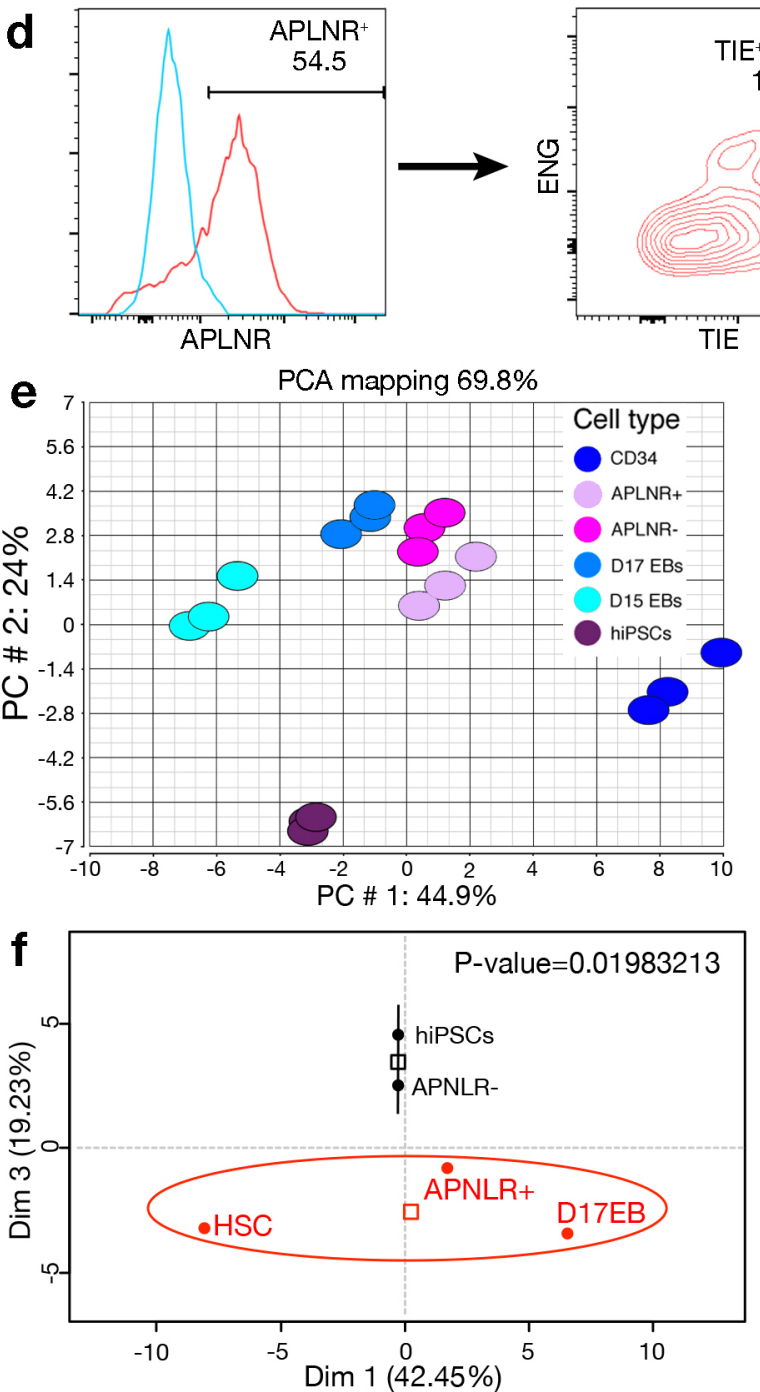

g

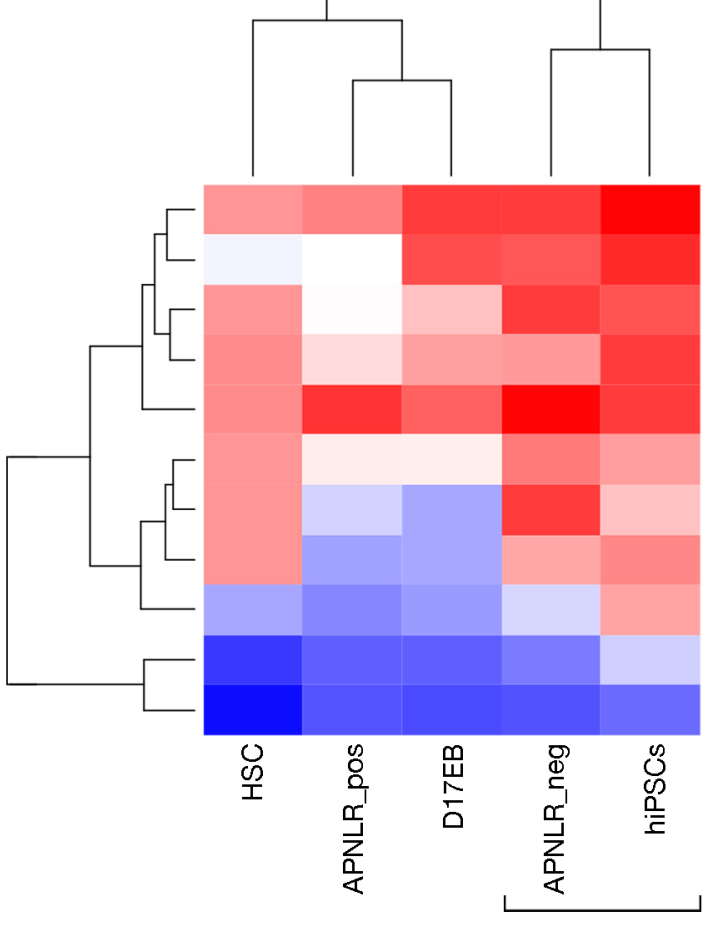

GATA3

IRF8

TEK

PECAM

STIL

RBPMS

KDR

MLLT3

RUNX1

RAG2

CEPBA

Cluster neg genes up 
bioRxiv preprint doi: https://doi.org/10.1101/177691; this version posted August 21, 2017. The copyright holder for this preprint (which was not certified by peer review) is the author/funder. All rights reserved. No reuse allowed without permission.

\section{Supplementary information}

Inventory of the supplementary figures and tables

\section{Supplementary figure 1 is related to Figure 1}

Shows the heat map of the gene list and the associated hierarchical clustering. It shows that CD $34^{+}$cells form a first main branch and that the EBs are segregated in a second main branch. D3 to D13 EBs are separated from 1D5 to D17 EBs.

\section{Supplementary figure 2 is related to Figure 2}

Endothelial and hematopoietic potential carried by D16 EBs in vivo.

\section{Supplementary figure 3 is related to Figure 3}

It gives a complete overview of the analysis of the hematopoietic engraftment with representative examples of multilineage reconstitution.

\section{Supplementary figure 4 is related to Figure 3}

Bone marrow analysis of the hematopoietic engraftment, multilineage reconstitution of primary recipients.

\section{Supplementary figure 5 is related to Figure 3}

A complete overview of the hematopoietic multilineage engraftment of peripheral blood, thymus and spleen from D17 EB cell and CB CD $34^{+}$HSPCs.

\section{Supplementary figure 6 is related to Figure 3}

Bone marrow analysis of the hematopoietic engraftment, multilineage reconstitution of secondary recipients.

\section{Supplementary figure 7 is related to Figure 4}

Characteristics of the $\mathrm{APLNR}^{+}$population in terms of hematopoietic engraftment.

\section{Supplementary table 1 is related to Figure 1}

Ex vivo endothelial and hematopoietic potential carried by hiPSC, HSC and D3 to D17 EBs.

\section{Supplementary table 2 is related to Figure 2}

Ex vivo endothelial and hematopoietic potential of EBs from D15 to D17.

\section{Supplementary table 3 is related to Figure 4}

Ex vivo endothelial and hematopoietic potential carried by hiPSC, CD34+ CB HSPC and APLNR+, APLNR- and D17 EBs. 
bioRxiv preprint doi: https://doi.org/10.1101/177691; this version posted August 21, 2017. The copyright holder for this preprint (which was not certified by peer review) is the author/funder. All rights reserved. No reuse allowed without permission.

\section{Supplementary Figure 1}
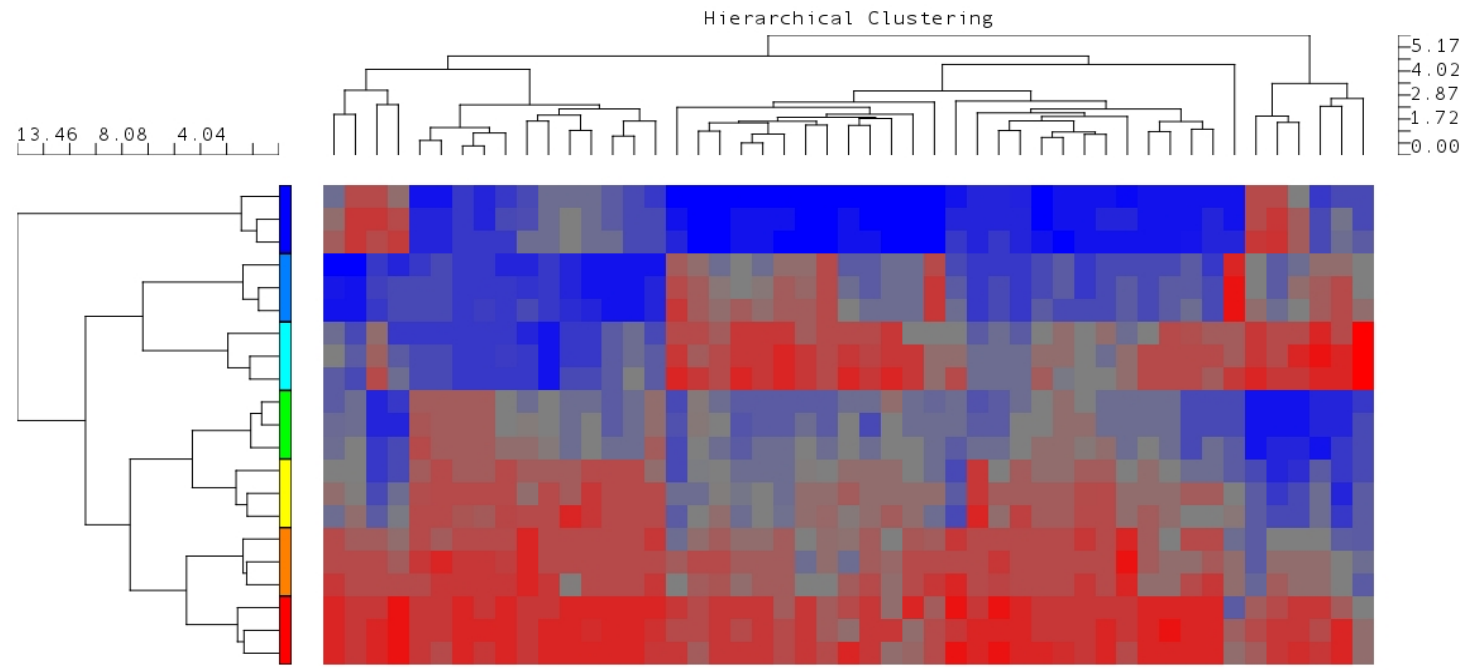

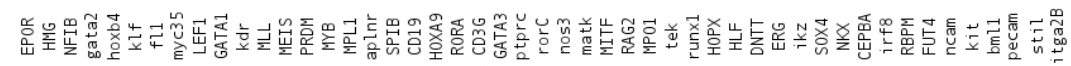

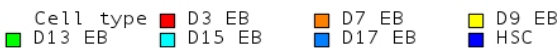




\section{Supplementary Figure 2.}

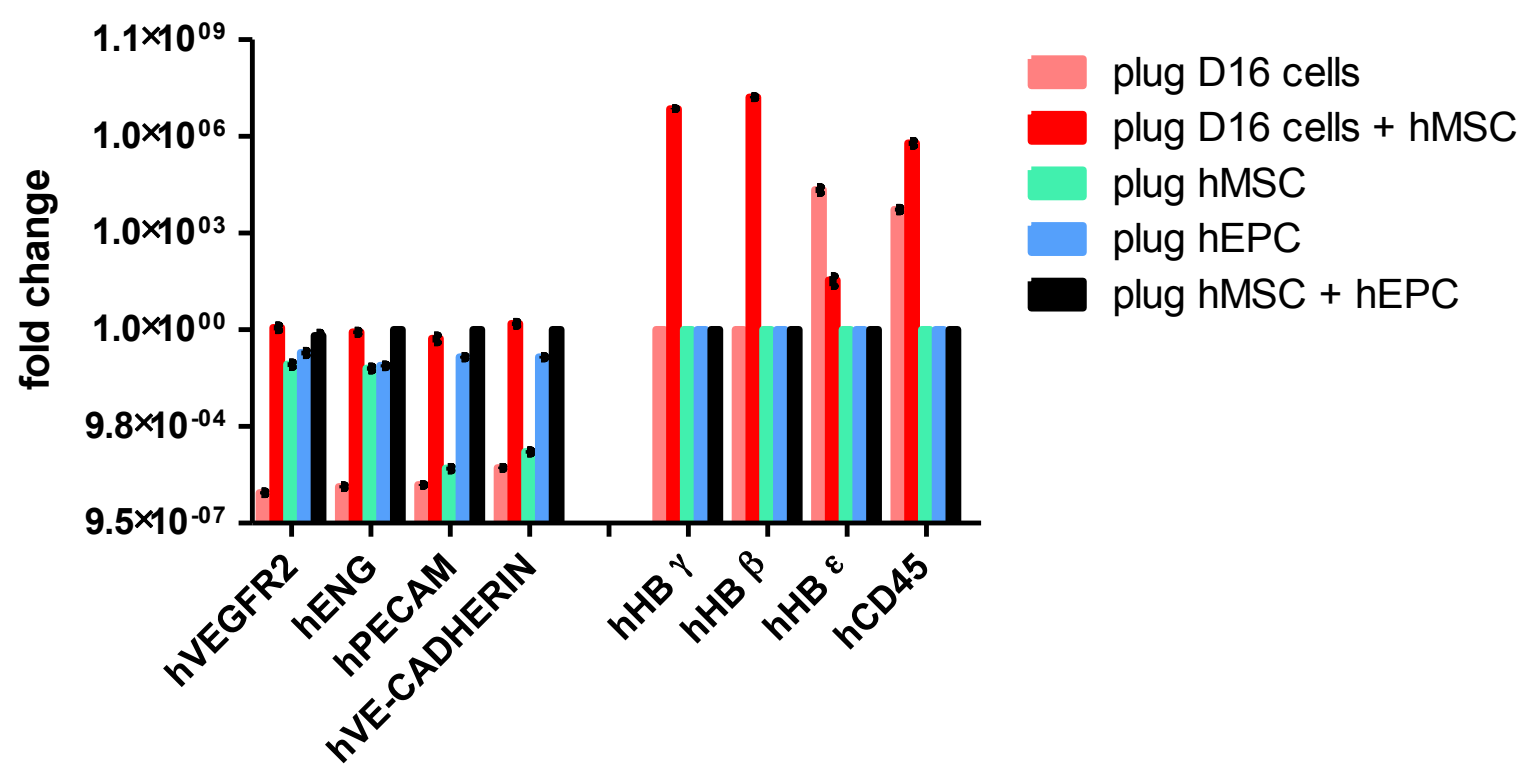


bioRxiv preprint doi: https://doi.org/10.1101/177691; this version posted August 21, 2017. The copyright holder for this preprint (which was not certified by peer review) is the author/funder. All rights reserved. No reuse allowed without permission.

\section{Supplementary Figure 3}

a
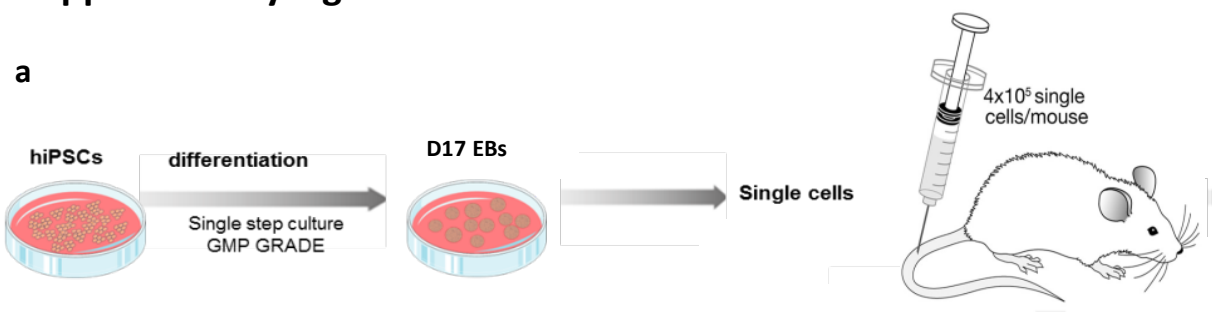

\begin{tabular}{|c|c|c|c|c|}
\hline & & culture & Facs analysis & $\begin{array}{c}\mathrm{qPCR} \\
\text { human genes }\end{array}$ \\
\hline \multirow{2}{*}{ Graft assessment } & \multirow{2}{*}{$\begin{array}{l}\text { Total bone } \\
\text { marrow }\end{array}$} & & $\mathrm{hCD} 45 / \mathrm{mCD} 45$ & \multirow{2}{*}{ GAPDH } \\
\hline & & & hCDd45/hCD $43 /$ hCD34 & \\
\hline \multirow{2}{*}{$\begin{array}{l}\text { Multilineage } \\
\text { assessment }\end{array}$} & $\begin{array}{l}\mathrm{hCD} 45 \text { bone } \\
\text { marrow sorting }\end{array}$ & & $\begin{array}{c}\text { hCD } 19 / \text { hCD } 20 \\
\text { hCD } 14 / \text { hCD } 15 \\
\text { hCD3 / hCD } 4 / \text { hCD } 8\end{array}$ & $\begin{array}{l}\text { CD45 } \\
\text { CD15 } \\
\text { MPO } \\
\text { ITGA2 } \\
\text { GAPDH }\end{array}$ \\
\hline & $\begin{array}{l}\text { hCD } 45 \text { blood } \\
\text { sorting }\end{array}$ & & $\begin{array}{c}\text { hCD19/hlgM } \\
\text { hCD14/hCD11B } \\
\text { hCD3 / hCD4 / hCD8 }\end{array}$ & \\
\hline Stemness assessment & $\begin{array}{l}\mathrm{hCD} 45 \text { bone } \\
\text { marrow sorting }\end{array}$ & Colony assays & & $\begin{array}{c}\text { Beta globin } \\
\text { Gamma globin } \\
\text { Epsilonglobin } \\
\text { GAPDH }\end{array}$ \\
\hline $\begin{array}{c}\text { Definitive } \\
\text { hematopoiesis } \\
\text { assessment }\end{array}$ & $\begin{array}{l}\text { Total bone } \\
\text { marrow }\end{array}$ & & hCD235a/hCD71 & $\begin{array}{c}\text { Beta globin } \\
\text { Gamma globin } \\
\text { Epsilonglobin } \\
\text { GAPDH }\end{array}$ \\
\hline \multirow{2}{*}{$\begin{array}{l}\text { B and T cells } \\
\text { functionality } \\
\text { assessment }\end{array}$} & $\begin{array}{l}\text { hCD } 45 \text { blood } \\
\text { sorting }\end{array}$ & & TCR $\alpha \beta, T C R \gamma \delta$ & \\
\hline & Thymus cells & $\begin{array}{l}\text { CFSE labeling } \\
\text { Stimulation with } \\
\text { hCD } 3 \text { and hCD } 28\end{array}$ & $\mathrm{hCD} 3 / \mathrm{hCD} 4 / \mathrm{hCD} 8$ & \\
\hline
\end{tabular}
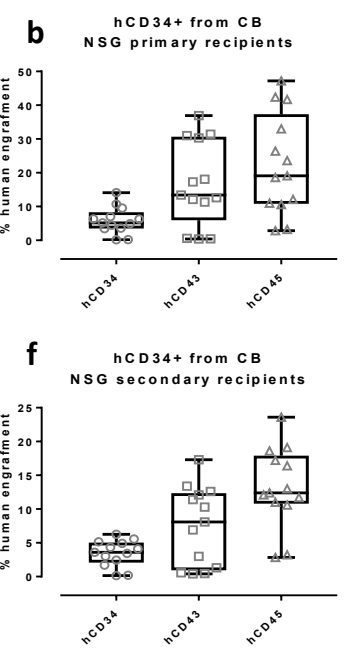

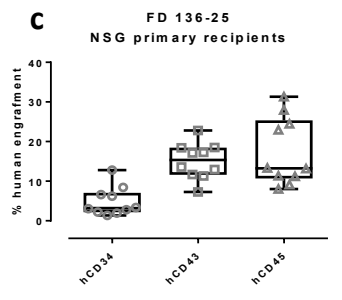

g NSG secondary $136-25$

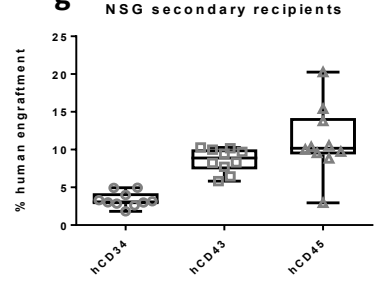

j

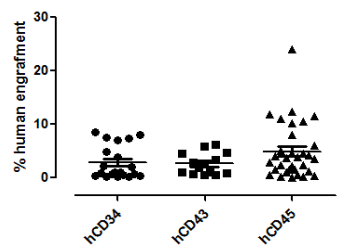

d PC1412
NSG primary recipients

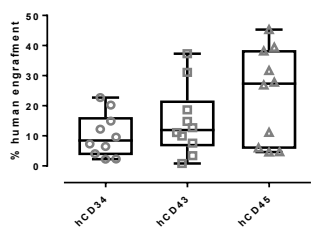

h $\mathrm{PC} 1412$

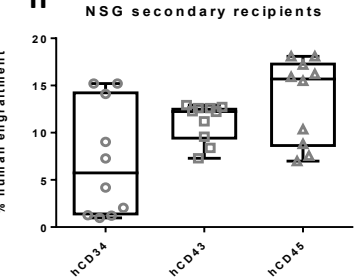

k

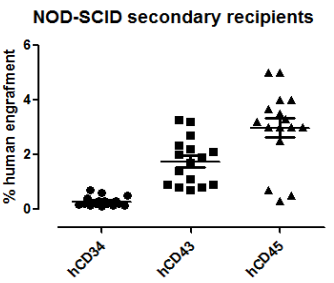

e $\quad \begin{gathered}\text { PC1426 } \\ \text { NSG primary recipients }\end{gathered}$
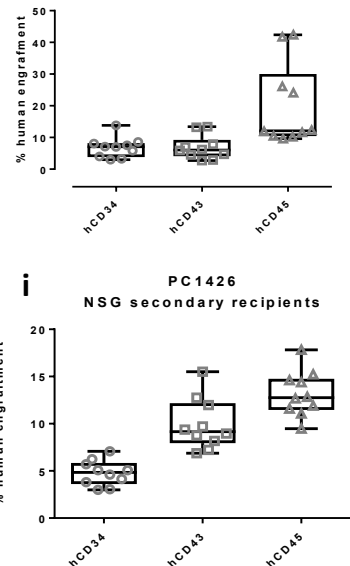

I

NOD-SCID tertiary recipients

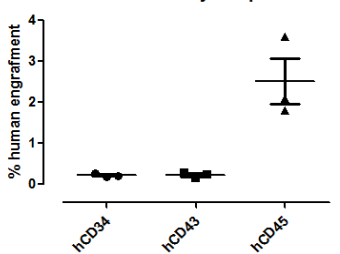


bioRxiv preprint doi: https://doi.org/10.1101/177691; this version posted August 21, 2017. The copyright holder for this preprint (which was not certified by peer review) is the author/funder. All rights reserved. No reuse allowed without permission.

\section{Supplementary Figure 4}
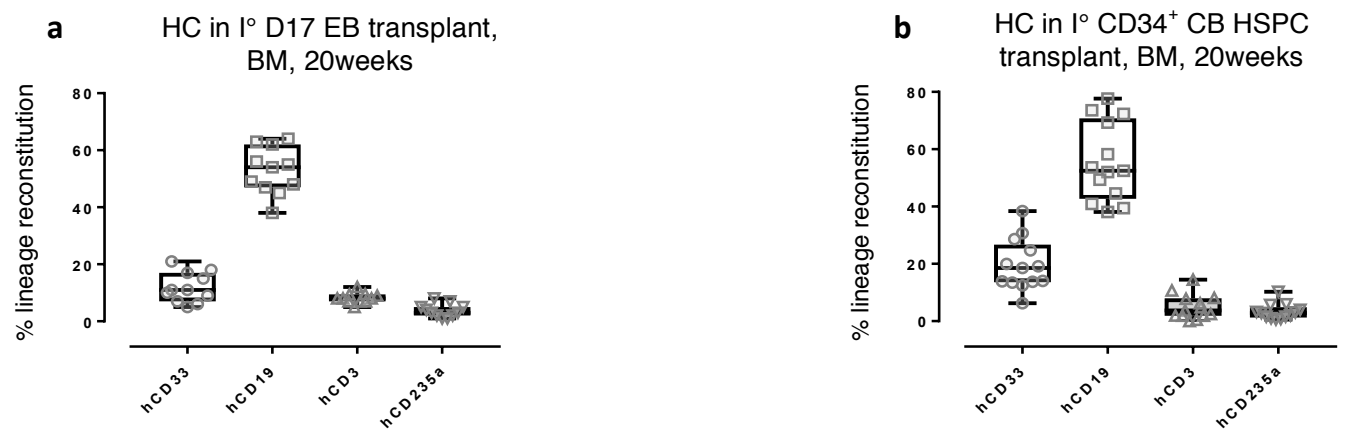

c .

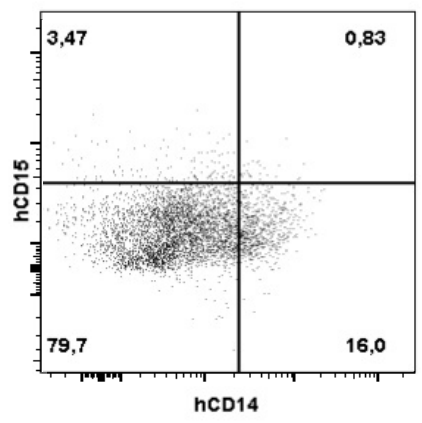

d .
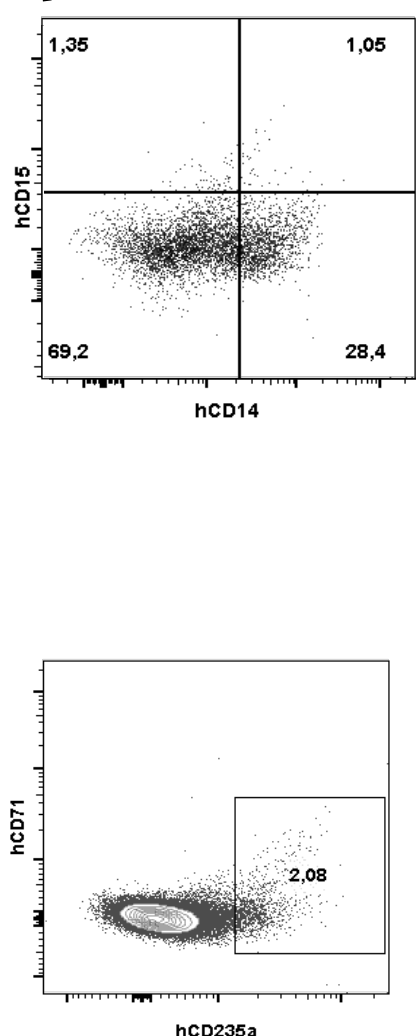

Multilineage analysis in $I^{\circ}$ D17 EB transplant
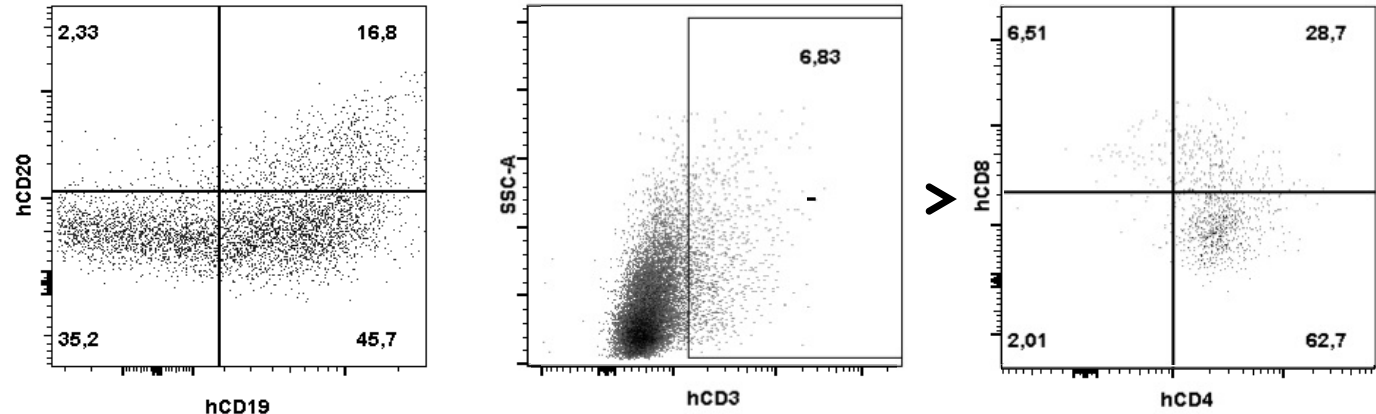

Multilineage analysis in $1^{\circ} \mathrm{CD} 34^{+} \mathrm{CB}$ HSPC transplant
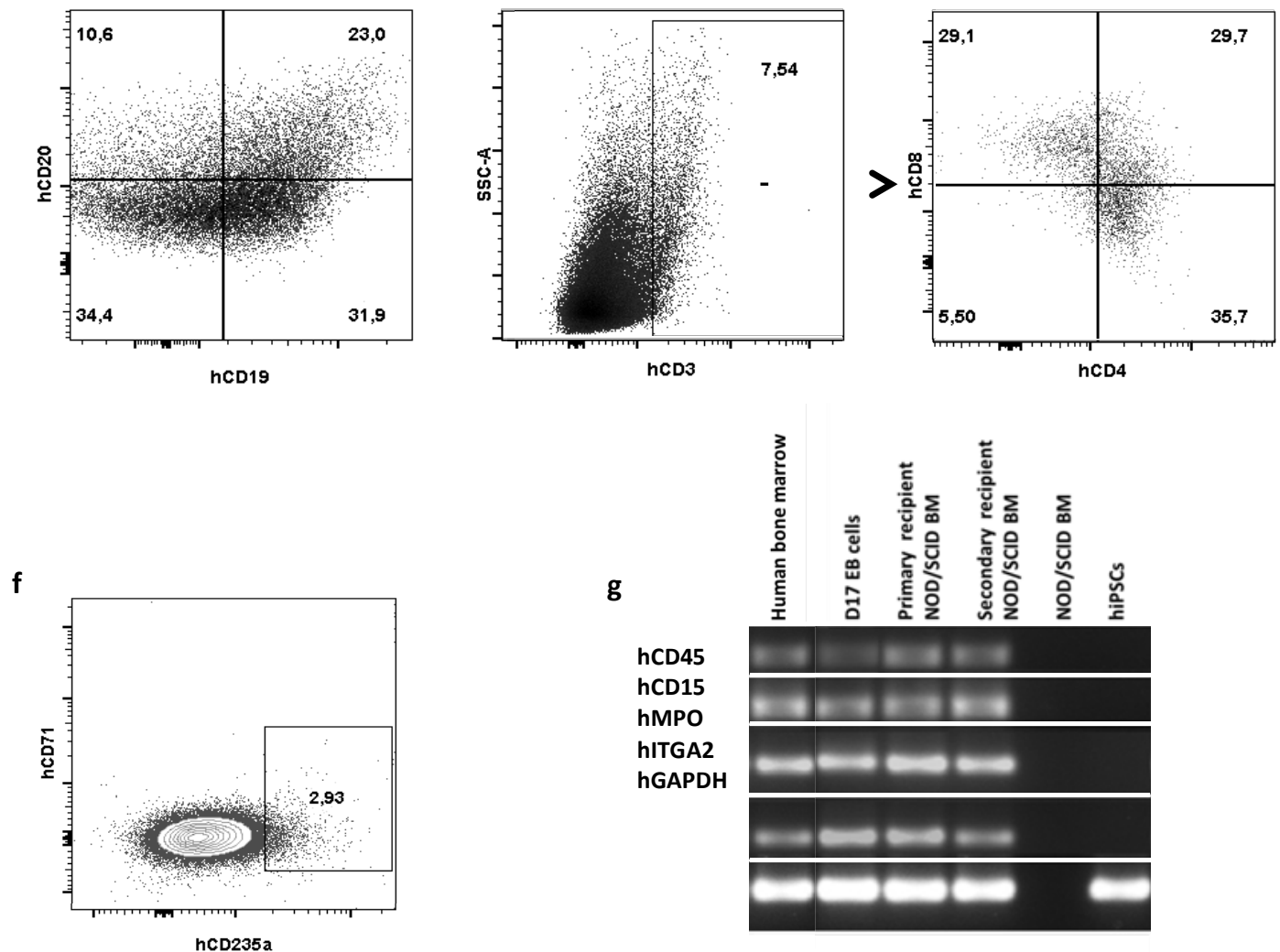

g

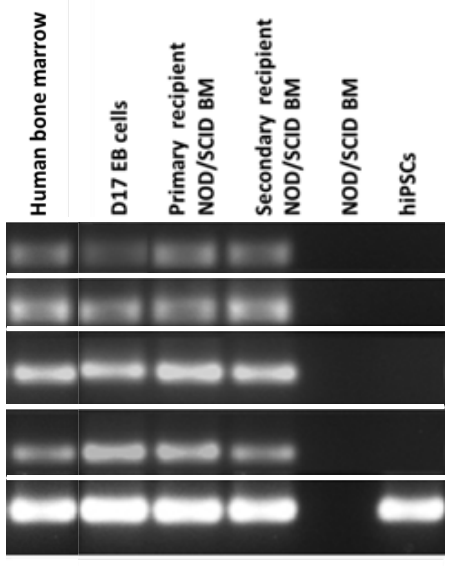


bioRxiv preprint doi: https://doi.org/10.1101/177691; this version posted August 21, 2017. The copyright holder for this preprint (which was not certified by peer review) is the author/funder. All rights reserved. No reuse allowed without permission.

\section{Supplementary Figure 5}

a

\section{Ungrafted NSG}

NSG

$I^{\circ}$ D17 EB

transplant

NSG

$I^{\circ} \mathrm{CD}^{+} 4^{+} \mathrm{CB}$ HSPC transplant

b

NSG

$I^{\circ}$ D17 EBs

transplant

\section{NSG}

$1^{\circ} \mathrm{CD}^{\circ} 4^{+} \mathrm{CB}$ HSPCs

transplant
Multilineage analysis

peripheral blood
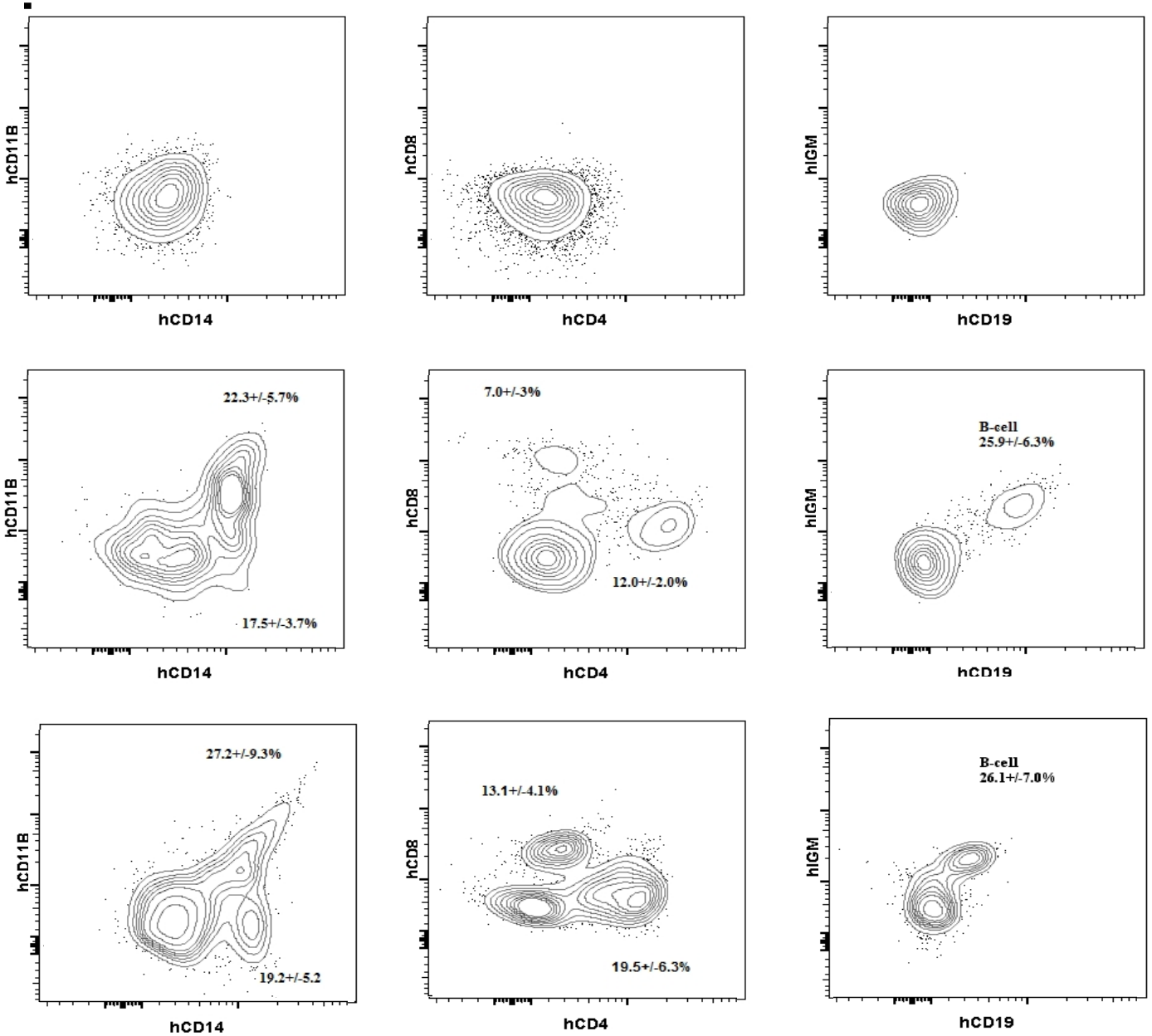

Multilineage analysis

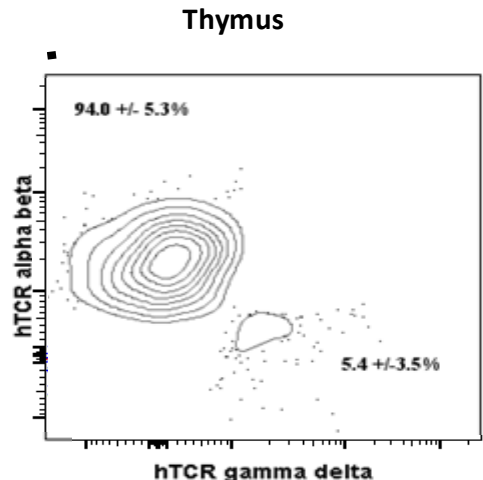

Spleen
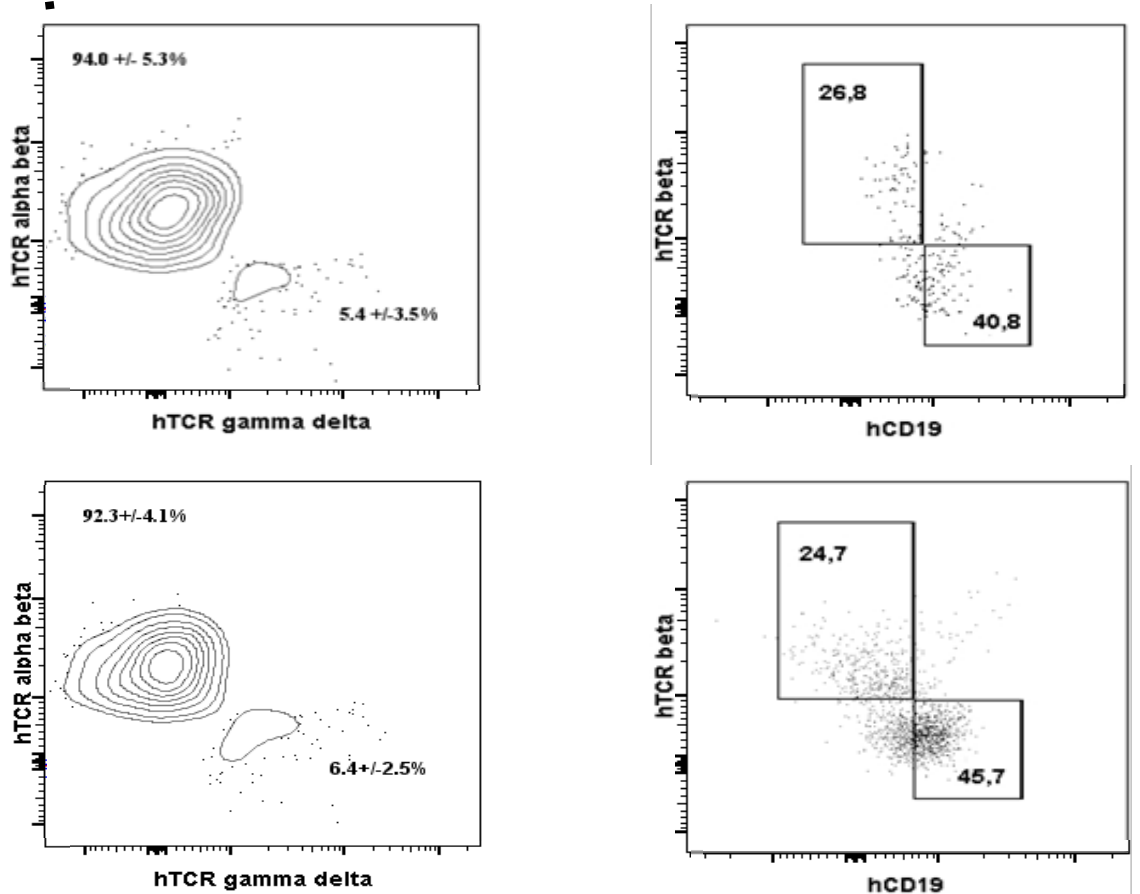
bioRxiv preprint doi: https://doi.org/10.1101/177691; this version posted August 21, 2017. The copyright holder for this preprint (which was not certified by peer review) is the author/funder. All rights reserved. No reuse allowed without permission.

\section{Supplementary Figure 6}

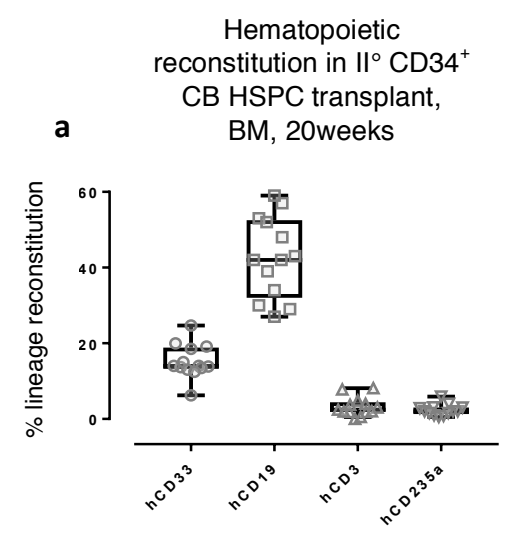

b

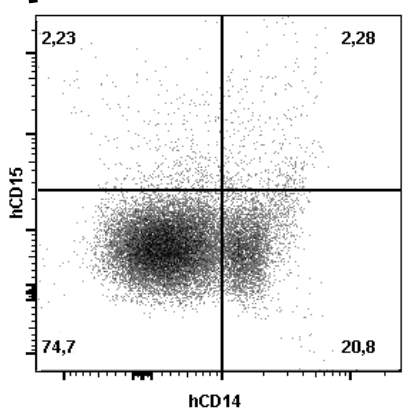

c

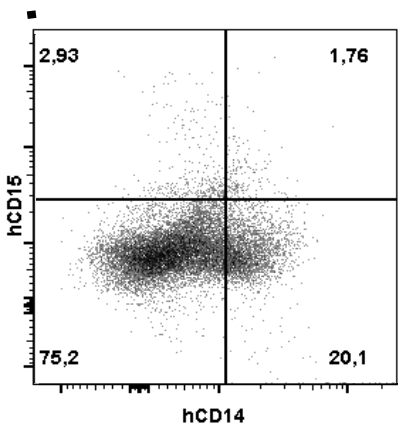

d

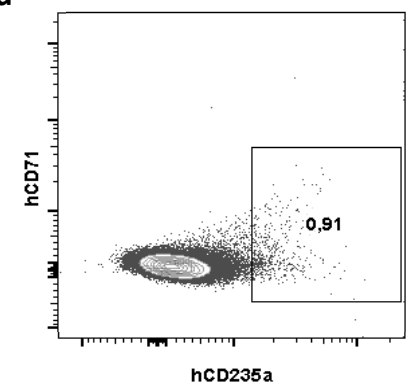

Multilineage reconstitution in $I^{\circ}$ D17 EB transplant
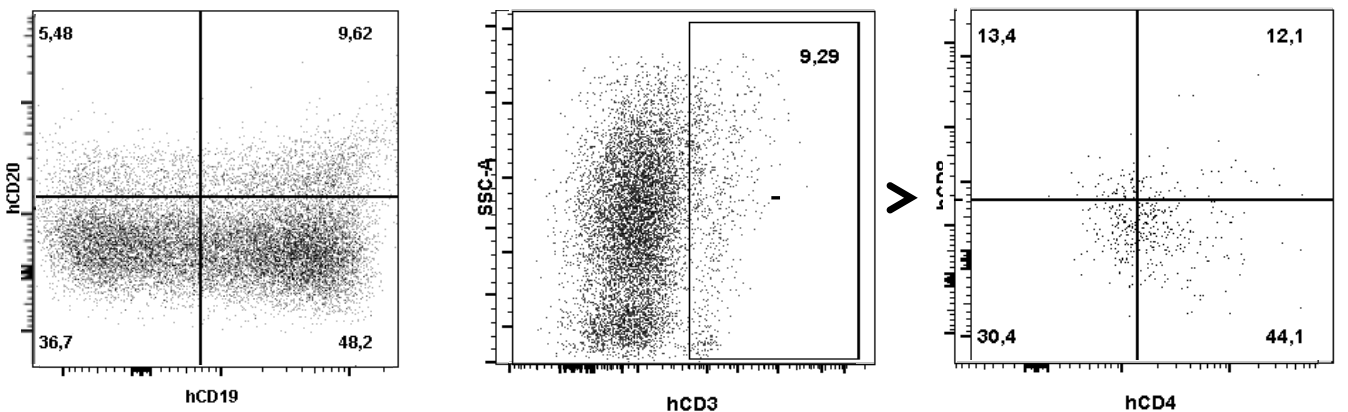

Multilineage reconstitution in $\mathrm{II}^{\circ} \mathrm{CD} 34^{+} \mathrm{CB}$ HSPC transplant
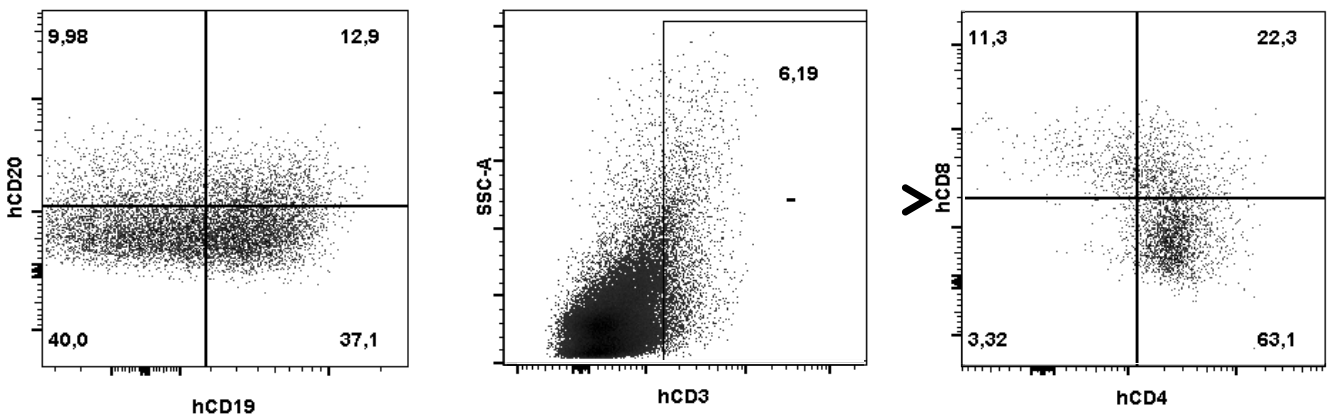

e

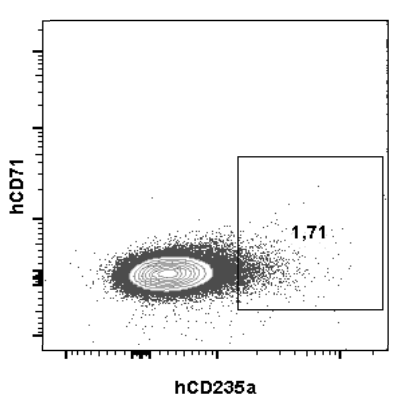


bioRxiv preprint doi: https://doi.org/10.1101/177691; this version posted August 21, 2017. The copyright holder for this preprint (which was not certified by peer review) is the author/funder. All rights reserved. No reuse allowed without permission.

\section{Supplementary Figure 7}

\section{$1^{\circ}$ APLNR cells transplant, BM, 20weeks}
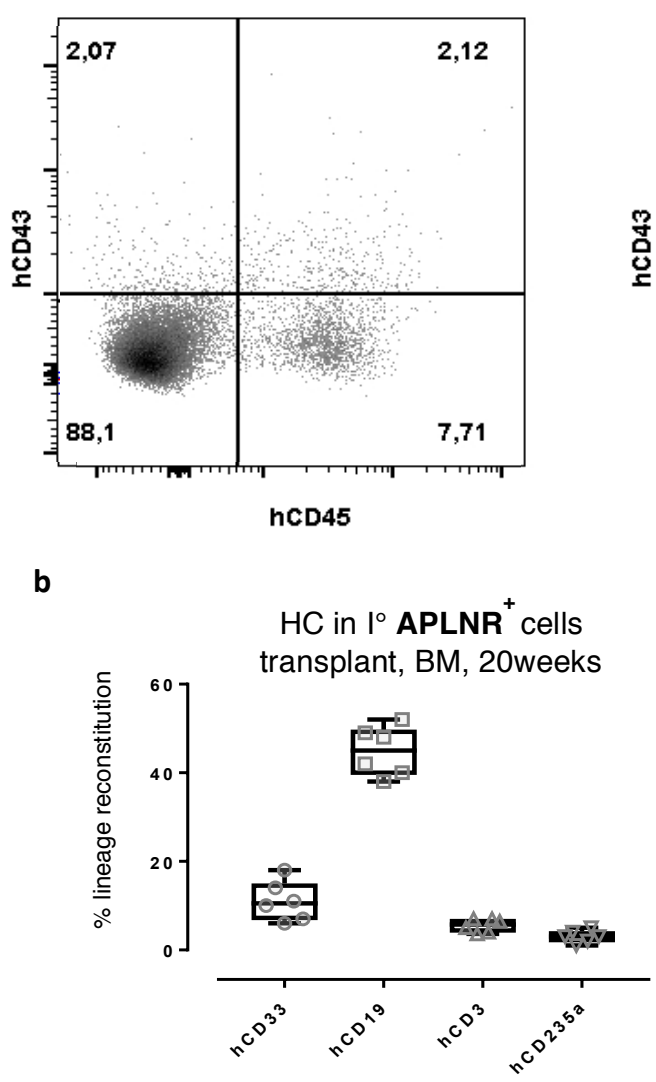

c Multilineage reconstitution in $1^{\circ}$ APLNR cells transplant
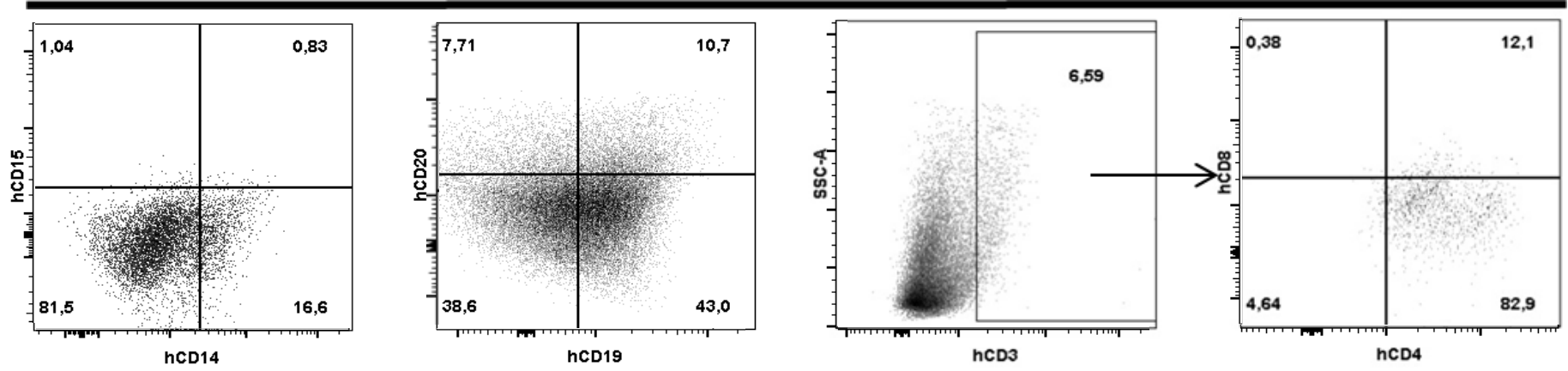

d

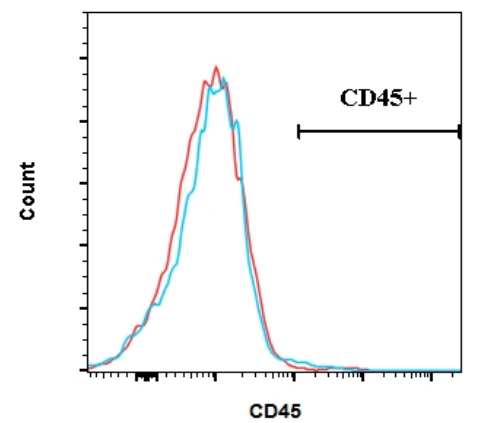

APLNR+ cells control isotype 
bioRxiv preprint doi: https://doi.org/10.1101/177691; this version posted August 21, 2017. The copyright holder for this preprint (which was not certified by peer review) is the author/funder. All rights reserved. No reuse allowed without permission.

Supplementary Legends

Supplementary Figure. 1. Hierarchical clustering and principal component analysis of the set of 49 genes representative of endothelial and hematopoietic commitment.

Heat map of the gene expression and the associated hierarchical clustering. CD $34^{+}$CB HSPCs are segregated from the EBs. D3 to D13 EBs are separated from D15 to D17 EBs.

Supplementary Figure 2. Endothelial and hematopoietic potential carried by D16 EBs in vivo.

Levels of expression of hVEGFR2, ENDOGLIN, PECAM-1, VE-CADHERIN, $\gamma$-globin, $\beta$-globin, $\varepsilon$ globin and CD45 in the matrigel plugs. For each gene, the fold change is the mean \pm SEM of 3 independent experiments.

Supplementary Figure 3. In vivo engraftment of D17 human EBs in immunocompromised mice.

(a) Experimental design. The table summarizes the different tests and analyses performed on the hematopoietic populations.

(b-I) In vivo engraftment capacity in immunocompromised mice. (b) CD $34^{+}$CB HSPCs in NSG primary recipient $(n=13)$ at 20 weeks post-graft after inoculation of $2 \times 10^{5}$ CD34+ cells. results are in $\%$ of $\mathrm{CD} 34^{+}, \mathrm{CD} 43^{+}$and $\mathrm{CD} 45^{+}$human cells. (c-e) D17 EBs from the three different hiPSCs lines (FD 136-25, PC1412 and PC1425) in NSG primary recipient $(n=30)$ at 20 weeks post-graft after inoculation of $4 \times 10^{5}$ D17 EBs. Results are in $\%$ of $C D 34^{+}, \mathrm{CD}_{4} 3^{+}$and 
bioRxiv preprint doi: https://doi.org/10.1101/177691; this version posted August 21, 2017. The copyright holder for this preprint (which was not certified by peer review) is the author/funder. All rights reserved. No reuse allowed without permission.

CD45 ${ }^{+}$human cells. (f-i) Follow up of the secondary recipients (f) NSG secondary recipient at

20 weeks post-graft after inoculation of $7 \times 10^{6}$ total BM cells from b. (g-i) NSG secondary recipient at 20 weeks post-graft after inoculation of $7 \times 10^{6}$ total BM cells from respectively c, d, e. (j-I) Follow up of D17 EBs from the FD136-25 hiPSC line grafted in primary $\left(e, 4 \times 10^{5}\right.$ cells, $n=20)$, secondary $\left(f, 7 \times 10^{6}\right.$ total $B M$ cells, $\left.n=16\right)$ and tertiary $\left(g, 7 \times 10^{6}\right.$ total $B M$ cells, $\mathrm{n}=3$,) NOD-SCID recipients. Results are in $\%$ of human $\mathrm{CD} 34^{+} \mathrm{CD} 43^{+} \mathrm{CD} 45^{+}$cells in mouse $\mathrm{BM}$ at 20 (e), 20 (f) and 12 (g) weeks after transplant. Data are mean +/- SEM.

\section{Supplementary Figure 4. Flow cytometry and qRT-PCR analysis of hematopoietic} engraftment in primary $B M$ recipients.

(a-b) Human hematopoietic cell lineages in primary recipients: (a) grafted with D17 EBs $(n=30)$ and (b) grafted with CD34 ${ }^{+}$CB HSPCs $(n=13)$. Cells were gated on hCD45+ expression for hCD33, hCD19 and hCD3 whereas hCD235a was analysed on whole BM cells. Data are mean +/- SEM.

(c-d) Flow cytometry analysis for myeloid (hCD14/hCD15) and lymphoid (hCD19/hCD20, SSC$\mathrm{A} / \mathrm{hCD} 3$ and $\mathrm{hCD} 4 / \mathrm{hCD} 8$ ) lineages from a representative NSG primary recipient grafted with D17 EB cells (c) or with CD34 ${ }^{+}$CB HSPCs (d). Analyses were performed on hCD45 ${ }^{+}$gated BM cells.

(e-f) Flow cytometry analysis of the erythroid lineage from a representative NSG primary recipient grafted with D17 EBs (e) or with CD34 ${ }^{+}$CB HSPCs (f). Analyses were performed on whole BM cells. 
bioRxiv preprint doi: https://doi.org/10.1101/177691; this version posted August 21, 2017. The copyright holder for this preprint (which was not certified by peer review) is the author/funder. All rights reserved. No reuse allowed without permission.

(g) qRT-PCR analysis for hCD45, hCD15, hMPO, hITGA2 and hGAPDH expression in human

BM cells (positive control), D17 EBs, NOD/SCID BM primary recipient grafted with D17 EBs, NOD/SCID BM secondary recipient, NOD/SCID BM ungrafted control, FD136-25 hiPSCs. PCR samples were run on several agarose gels. For presentation purpose, bands were assembled one above the other (white lines).

Supplementary Figure 5. Flow cytometry analysis of human hematopoietic lineages from representative primary recipients peripheral blood, thymus and spleen.

(a) Myeloid (hCD11B/hCD14) and lymphoid (hCD19/hIGM and hCD4/hCD8) lineages on peripheral blood of ungrafted recipient $\left(1^{\text {st }}\right.$ line $)$, of D17 EBs grafted recipient ( $2^{\text {nd }}$ line) and of $\mathrm{CD} 34^{+} \mathrm{CB}$ HSPCs grafted recipient ( $3^{\text {rd }}$ line). The analyses were performed on $\mathrm{hCD} 45^{+}$ gated cells, aside the ungrafted recipient.

(b) Representative flow cytometry analysis of thymus and spleen cells. Thymus hCD3 gated cells exhibited a large amount of TCR alpha beta cells very close to that obtained using CD34 ${ }^{+}$ CB HSPCs. $h C D 45^{+}$gated spleen cells exhibited B or T lymphoid phenotype with ratios similar to those obtained with CD34 ${ }^{+}$CB HSPCs.

Supplementary Figure 6. Flow cytometry analysis of hematopoietic engraftment in secondary BM recipients.

(a) Human hematopoietic lineage distribution in secondary recipients grafted with $7.10^{6}$ whole bone marrow from $\mathrm{CD} 34^{+} \mathrm{CB}$ HSPCs-grafted primary recipient $(n=13)$. Cells were 
bioRxiv preprint doi: https://doi.org/10.1101/177691; this version posted August 21, 2017. The copyright holder for this preprint (which was not certified by peer review) is the author/funder. All rights reserved. No reuse allowed without permission.

gated on hCD45+ expression for hCD33, hCD19 and hCD3 whereas hCD235a was analysed

on whole BM cells. Data are mean +/- SEM.

(b-c) Flow cytometry analysis of the myeloid (hCD14/hCD15) and lymphoid (hCD19/hCD20, SSC-A/hCD3 and hCD4/hCD8) lineages. (b) From a representative NSG secondary recipient grafted with $7.10^{6}$ whole BM from D17 EB primary recipient. Analyses were performed on hCD45 ${ }^{+}$gated BM cells. (c) From a representative NSG secondary recipient grafted with $7.10^{6}$ whole BM from $\mathrm{CD} 34^{+} \mathrm{CB}$ HSPCs-grafted primary recipient.

(d-e) Representative flow cytometry analysis of the erythroid lineage. Analyses performed on whole BM cells. : (d) Representative NSG secondary recipient grafted with $7.10^{6}$ whole BM of D17 EBs primary recipient and (e) Representative NSG secondary recipient grafted with $7.10^{6}$ whole BM CD34 ${ }^{+}$CB HSPCs-grafted primary recipient.

\section{Supplementary Figure 7. Characterization of the $\mathrm{APLNR}^{+}$and $\mathrm{APLNR}^{-}$populations.}

(a) Representative profile of hCD45 and hCD43 expression in mice BM grafted with either the D17 APLNR ${ }^{+}$(left) or ${ }^{-}$(right) cell fractions.

(b) Human hematopoietic lineage distribution in primary BM recipient grafted with APLNR ${ }^{+}$ cells $(n=6)$. Data are mean $+/-$ SEM.

(c) Representative flow cytometry analysis of the myeloid (hCD14/hCD15) and lymphoid (hCD19/hCD20, SSC-A/hCD3 and hCD4/hCD8) lineages present in a primary BM recipient grafted with APLNR ${ }^{+}$cells. 
bioRxiv preprint doi: https://doi.org/10.1101/177691; this version posted August 21, 2017. The copyright holder for this preprint (which was not certified by peer review) is the author/funder. All rights reserved. No reuse allowed without permission.

(d) Representative flow cytometry analysis showing the absence of CD45 expression on

$\mathrm{APLNR}^{+}$cells 
bioRxiv preprint doi: https://doi.org/10.1101/177691; this version posted August 21, 2017. The copyright holder for this preprint (which was not certified by peer review) is the author/funder. All rights reserved. No reuse allowed without permission.

\section{Supplementary Tables}

Supplementary Table 1. Ex vivo endothelial and hematopoietic potential carried by hiPSC, CD34 ${ }^{+}$CB HSPC and D3 to D17 EBs.

Refer to the attached supptable1.xlsx file. 


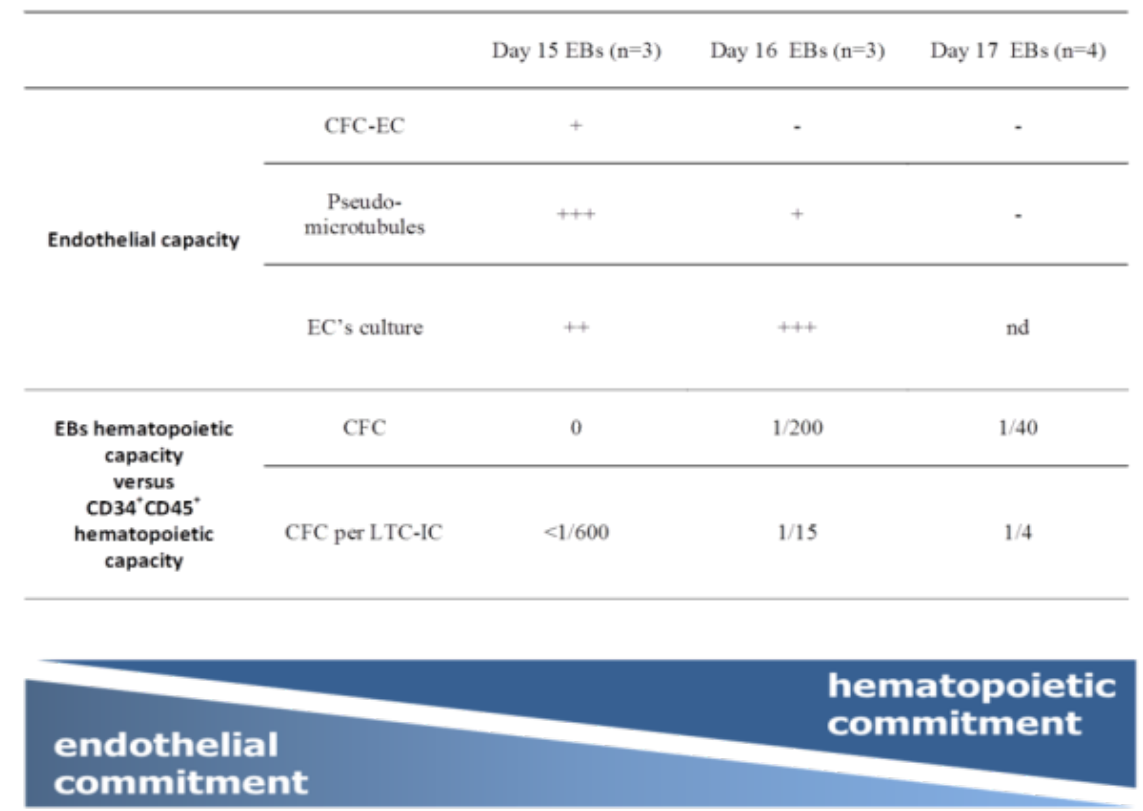

\section{Supplementary Table 2. Endothelial and hematopoietic potential carried by D15 to D17} EBs ex vivo.

EBs were probed for their capacities to give rise to either EC or $\mathrm{HC}$ colonies based on recognized functional tests. The highest endothelial potential was found at D15, markedly decreased at D16 and was absent at D17. In contrast, the hematopoietic potential was first detected at D16 and was high at D17.

Legend: EB: embryonic bodies; LTC-IC: Long Term Culture-Initiating Cells; CFC: ColonyForming Cell. 
bioRxiv preprint doi: https://doi.org/10.1101/177691; this version posted August 21, 2017. The copyright holder for this preprint (which was not certified by peer review) is the author/funder. All rights reserved. No reuse allowed without permission.

Supplementary Table 3. Ex vivo endothelial and hematopoietic potential carried by hiPSC, CD34 ${ }^{+}$CB HSPC and APLNR ${ }^{+}$, APLNR ${ }^{-}$and D17 EBs.

Refer to the attached supptable3.xlsx file. 
bioRxiv preprint doi: https://doi.org/10.1101/177691; this version posted August 21, 2017. The copyright holder for this preprint (which was not certified by peer review) is the author/funder. All rights reserved. No reuse allowed without permission.

hiPSC_1 hiPSC_2 hiPSC_3 D3 EBs_1 D3 EBs_2 D3 EBs_3 D7 EBs_1

D7 EBs_2 D7 EBs_3 D9 EBs_1 D9 EBs_2 D9 EBs_3 D13 EBs_1

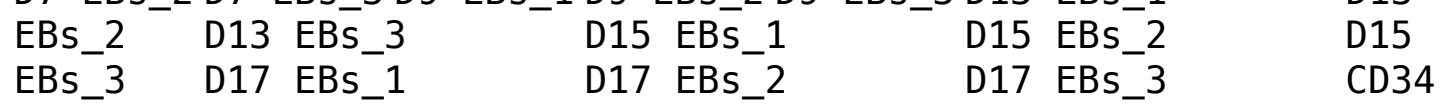

HSPCS_1 CD34 HSPCs_2

$\mathrm{HOPX}$

9.9853

6.2102

0.2861

RBPM

10.4622

10.4894

3.9029

PRDM

8.5028

7. 3714

9.7502

6.0942

7.0732

CD34 HSPCs_3

3.8602

3.8168

NKX

14.0516

15.9205

3.8908

GATA3

14.2512

19. 5109

4.1292

TEK

11.6596

8.6071

4.1491

N0S3

4.0737

9.3740

6.6233

13. 3164

8.8180

10.8621

2.9681

2.6392

13.2554

13.6364

6.7338

6.3784

10.5444

3.7816

3.4865

12.0818

2.2135

1.0406

7.1156

$11.1729 \quad 9.6973$

$10.0099 \quad 9.8023$

6. 2481

9. 2207

6.4327

7.8417

8.5548

12.0361

12.4018

6.7166

6.5380

7.9122

6.8338

10.0581

4.1314

8.9212

5.7977

11.0850

8.3635

9.0746

5.9919

4.6664

3.5279

$-0.7339$

$-0.4540$

11.0518

11.4050

9.0673

$8.9189 \quad 9.0755$

8.4508

18.8239

$-1.2654$

4.3735

4.4036

$13.6140 \quad 13.7424$

13.2024

14.0354

18.6945

4.4435

4.6541

16.2438

12.0193

9.4827

9.5973

12.1006

$18.6562 \quad 14.5958$

$10.2627 \quad 10.3681$

9.8175

19.5774

8.8511

11.7649

11.8710

$14.8428 \quad 15.8103$

15.1308

15.7498

19.9357

4.5224

4.6541

20.1576

17.0843

16.3061

16.6025

14.8763

$19.3531 \quad 13.6532$

15.8884

12.403913 .5076

$4.6664 \quad 4.7392$

6.6877

6.9123

6.2624

13. 1168

13.9377

14.3273

12.1146

12.3660

13.7268

13.2512

13.9444

8.4572

7.1540

7.4739

8.7656

11.3284

7.9550

5.5029

5.7497

5.0712

4.6664

4.6541

15. 9851

17.3272

11.7808

11.0486

19.1094

15.5785

15.0454

15.2645

18.9764

18.6215

16.5221

18.3889

4. 3299

MATK

5. 4948

18.2240

12.3298

12.8229

13.2662

12.9348

11.2083

11.9933

4.6664

5.0028

8.7035

9.7284

5.6179

5.0033

9.0663

9.6657

12.8194

9.7967

12.9506

13.3972

9.5438

9. 3911

10. 2241

8.3670

9.5993

8.7393

0.1638

MITF

8.1788

8.4535

7.7597

8.0673

7.4200

0.6980

0.8962

16. 8891

18.4583

7.8257

17. 1308

14.8994

4.7440

HMG

2.9381

1.0296

4.6541

MEIS

8.4318

1.4695

4.3607

MLL

17.4936

15.8103

15. 1308

19. 5774

16.0575

16.0192

17.8103

18.4342

14.8675

14.6030

15.9637

14.8763

14.4037

14.5437

8.5481

10.0255

10.5624

9.7133

19.5774

14.092

8.4066

17.8103

17.8171

15.8103

15.1308

15.8171

14.8763

19.5477

14.4037

14.3970

16.1316

14.0049

11.1736

11.8465

11.1662

5.0447

5.5719

$\begin{array}{llll}-1.3810 & -1.6508 & -1.9730 & 4.9250\end{array}$

3.6764

1.7828

1.1989

1.9362

4.9682

5.2449

3.5230

$-0.0661$

4.3034

4.9645

8.6233

2.0969

5.4892

$-1.2771$

$-4.2257$

1.3622

0.9870

$-4.6088-4.9812$

4.6664

4.7154

11.0528

11.0199

$10.6818 \quad 8.9966$

1.1000

8.8722

9.4895

5.4137

5.0535

8.9966

$-0.9310$

$-0.3504$

$-1.2367$

4.6664

5.4066

2.5769

3.4352

$2.2761 \quad 9.8497$

10.5028

$10.1927 \quad 7.2192$ 
bioRxiv preprint doi: https://doi.org/10.1101/177691; this version posted August 21, 2017. The copyright holder for this preprint (which was not certified by peer review) is the author/funder. All rights reserved. No reuse allowed without permission.

\begin{tabular}{|c|c|c|c|c|c|c|c|}
\hline 7.1551 & 5.0987 & 6.9688 & 6.4897 & 10.6278 & 4.2281 & 3.5527 & 4.1243 \\
\hline $\begin{array}{l}0.1483 \\
4.2021\end{array}$ & 1.4081 & 0.4149 & -0.7987 & 0.1009 & -1.1079 & 4.6664 & 4.6541 \\
\hline IRF8 & 9.1168 & 10.0666 & 9.0463 & 19.2218 & 19.9357 & 19.3586 & 13.9610 \\
\hline 17.1308 & 16.6983 & 15.6409 & 11.1636 & 12.7477 & 79 & 117 & 8355 \\
\hline $\begin{array}{l}16.0534 \\
2.8577\end{array}$ & 17.0795 & 15.7855 & 10.7760 & 11.7956 & 10.6941 & 3.0656 & 4.2763 \\
\hline RUNX1 & 4.5033 & 4.8527 & 4.0825 & 10.1772 & 10.1867 & 9.2439 & 7.7288 \\
\hline 7.2491 & 4296 & 6.0467 & 4.7498 & 5.4420 & 3.9484 & 351 & 3319 \\
\hline $\begin{array}{l}3.7874 \\
0.0752\end{array}$ & 4.0487 & 3.6351 & 1.8341 & 2.0904 & 1.3214 & 0.5525 & 0.9204 \\
\hline KDR & 0.3740 & 0.7412 & 0.0466 & 10.2469 & 11.5504 & 11.5122 & 9.3294 \\
\hline .3478 & 10.1808 & 8.5188 & 7.9954 & 8.8284 & 5.7831 & 3568 & \\
\hline $\begin{array}{l}5.4968 \\
4.6541\end{array}$ & $\begin{array}{l}-2.5139 \\
4.2470\end{array}$ & -2.4042 & -2.5584 & 0.4948 & 0.8634 & 0.1555 & 4.6664 \\
\hline FLI1 & 5.2316 & 5.4024 & 4.7735 & 19.5774 & 19.9357 & 19.6188 & 17.8103 \\
\hline 17.1308 & 17.7204 & 103 & 15.1308 & 15.5266 & 14.8763 & 4037 & 14.5437 \\
\hline $\begin{array}{l}5.2316 \\
4.7735\end{array}$ & 5.4024 & 4.7735 & 5.2316 & 5.4024 & 4.7735 & 316 & 5.4024 \\
\hline MYC & 1.2180 & 1.7 & 0.9357 & 928 & 512 & 325 & 5.8577 \\
\hline 5.3499 & 6.5120 & 3. & 2.8 & 566 & 711 & 159 & \\
\hline $\begin{array}{l}2.8709 \\
-9.5781\end{array}$ & $\begin{array}{l}-7.9068 \\
-10.3890\end{array}$ & -8.1330 & -8.7345 & -7.9401 & -7.4231 & -8.2119 & -10.0795 \\
\hline HOXB4 & 6.0216 & 6.1387 & 5.5368 & 8.6522 & 8.5261 & 8.2073 & 7.8336 \\
\hline 6.8078 & 7. 1817 & 5.8433 & 5.5 & 133 & 5. & 5.0267 & \\
\hline $\begin{array}{l}5.7937 \\
-4.9096\end{array}$ & $\begin{array}{l}-1.1602 \\
-5.5225\end{array}$ & -0.8976 & -2.6499 & -1.5792 & -1.4416 & -2.0085 & -5.0263 \\
\hline NFIB & 4.5185 & 4.4276 & 3.9068 & 8.2167 & 8.8587 & 8.5744 & 7.0850 \\
\hline 6.8654 & 7.6433 & 3.9541 & 2.8493 & 4.2543 & 2.8547 & 3207 & 2.1265 \\
\hline $\begin{array}{l}6.4076 \\
7.1720\end{array}$ & 7.5474 & 6.0778 & 3.3816 & 3.1509 & 2.6873 & 1706 & 7.3624 \\
\hline RAG2 & 3.2504 & 3.3148 & 2.7597 & 1.7425 & 2.2910 & 3.0163 & 2.6533 \\
\hline 2.0198 & 3.5713 & 0.5403 & -0.6392 & -0.4012 & -0.5334 & -1.1539 & -0.8860 \\
\hline 0.4973 & 0.4935 & -0.0518 & 3.3718 & 3.2147 & & & \\
\hline 2.7047 & -7.0681 & -7.4822 & -7.5066 & & & & \\
\hline SPIB & -2.2027 & -2.1636 & -2.7222 & 14.1956 & 13.4104 & 13.7933 & 13.8401 \\
\hline 12.1497 & 13.3049 & 9.9993 & 10.1805 & 10.8849 & 10.7524 & 11.1396 & 11.1450 \\
\hline 13.5194 & 16.2929 & 13.8033 & 12.6414 & 12.6288 & & & \\
\hline 12.0653 & -0.8492 & -0.2420 & -0.9642 & & & & \\
\hline SOX4 & 10.4954 & 10.1914 & 9.1848 & 15.7257 & 15.6348 & 16.0457 & 17.8103 \\
\hline 16.7660 & 17.4537 & 13.4747 & 12.9338 & 13.6281 & 12.2670 & 11.9319 & 11.9343 \\
\hline $\begin{array}{l}13.7376 \\
6.8193\end{array}$ & 13.2264 & 12.3050 & 11.4967 & 11.2336 & 10.1767 & 8.2218 & 7.7004 \\
\hline MYB & 5.7862 & 5.7702 & 5.1635 & 15.2467 & 15.1617 & 1235 & 12.9687 \\
\hline 12.4185 & 13.2515 & 12.9298 & 12.3869 & 13.2198 & 9.0614 & 8.7145 & 8.8545 \\
\hline $\begin{array}{l}9.4659 \\
6.7525\end{array}$ & 9.6166 & 9.4207 & 3.2386 & 3.2335 & 2.5982 & 7.4350 & 7.3877 \\
\hline HOXA9 & 12.6539 & 13.6803 & 12.1869 & 19.5774 & 19.9357 & 19.0150 & 17.8103 \\
\hline 17.1308 & 16.8642 & 15.8103 & 15.1308 & 15.4163 & 14.8763 & 14.4037 & 14.0700 \\
\hline $\begin{array}{l}20.1234 \\
8.8499\end{array}$ & 21.5431 & 19.3669 & 16.4051 & 17.4507 & 15.9109 & 9.3995 & 10.2691 \\
\hline ERG & 5.8874 & 6.2409 & 5.4849 & 14.4151 & 15.5593 & 5210 & 13 \\
\hline 4.5256 & 15.3585 & 12.6419 & 11.9463 & 12.7792 & 9.9676 & 9.9155 & 10.0555 \\
\hline 30 & 9.8957 & 9.44 & 4.6106 & 5.1559 & 4.2727 & $\theta$ & \\
\hline
\end{tabular}


bioRxiv preprint doi: https://doi.org/10.1101/177691; this version posted August 21, 2017. The copyright holder for this preprint (which was not certified by peer review) is the author/funder. All rights reserved. No reuse allowed without permission.

\begin{tabular}{|c|c|c|c|c|c|c|c|}
\hline ROR & 885 & 143 & 56 & 77 & 1 & 1 & $816 \quad-2$ \\
\hline 7.1308 & 8171 & 15.8103 & 1308 & & & & \\
\hline $\begin{array}{l}20.2953 \\
7.7562\end{array}$ & 20.4542 & 19.5193 & 16.4397 & 17.0447 & 15.4431 & 8.8263 & 9.4026 \\
\hline LEF & 3.3233 & 3.0408 & 2.4735 & 10.2337 & 111 & .5537 & 8.3351 \\
\hline 579 & & 8.7 & & & & & \\
\hline 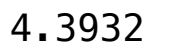 & -0.0990 & -0.1473 & -1.1553 & -1.1492 & -1.4735 & -2.0176 & \\
\hline & -0 & -0.5986 & & & & & \\
\hline$A$ & 3. & 3. & 3. & 8.2969 & 8.2983 & 14 & 2.7402 \\
\hline & & & & & & & 23 \\
\hline & 5. & & & & & & \\
\hline בסט & -0 & & -4.7972 & -5 & -5 & & \\
\hline$P C$ & 6. & & & 50 & & 3 & 831 \\
\hline 24 & & & & & & & \\
\hline 7.5 & 6. & & & & & & \\
\hline & & & & & & & \\
\hline 08 & & & & & & & \\
\hline 7.8 & $7 . e$ & & & & & & \\
\hline IK & .6 & & & & & & \\
\hline 750 & & & & & & & \\
\hline & 8.3 & & & & & & \\
\hline KLT & & & & & & & \\
\hline 79 & & & & & & & \\
\hline & 10 & & & & & & 6 \\
\hline & & & & & & & \\
\hline API & & & & & & & \\
\hline 17 & & & & & & & \\
\hline & 11 & & & & & & \\
\hline Ch & & & & & & & \\
\hline & 4. & & & & & & \\
\hline & 9. & & & & & & \\
\hline PECAM & & & & & & & \\
\hline & & & & & & & \\
\hline $\begin{array}{l}14 . \\
7.1\end{array}$ & 14 & & & & & & \\
\hline PTPRC & 9. & & & & & & \\
\hline & & & & & & & \\
\hline & 8.4459 & & & & & & \\
\hline & -1.1682 & & & & & & \\
\hline RORC & 15. & & & & & & 42 \\
\hline 15.0846 & 16. & & & & & & 437 \\
\hline 18.2071 & 18.6152 & 17 & 1 & & & 9. & 9.6241 \\
\hline FUT4 & 4.5 & & & & & & \\
\hline 1.0635 & 2.4 & & 0.4176 & 1.8 & -0.0623 & -0.5931 & 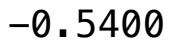 \\
\hline 3.0826 & & 2.8111 & 6.4065 & 130 & & & \\
\hline 5. & -3.2 & -2.5714 & -3.6297 & & & & \\
\hline & (1) & $1 / .344$ & 10.1144 & $10.03<8$ & $13.89<0$ & 15.5785 & 14.748 \\
\hline
\end{tabular}


bioRxiv preprint doi: https://doi.org/10.1101/177691; this version posted August 21, 2017. The copyright holder for this preprint (which was not certified by peer review) is the author/funder. All rights reserved. No reuse allowed without permission.

\begin{tabular}{|c|c|c|c|c|c|c|c|}
\hline $\begin{array}{l}13.2436 \\
16.5968 \\
8.8922\end{array}$ & $\begin{array}{l}13.8934 \\
17.1793\end{array}$ & $\begin{array}{l}13.2144 \\
15.4520\end{array}$ & $\begin{array}{l}11.7176 \\
15.5791\end{array}$ & $\begin{array}{l}12.7121 \\
16.1511\end{array}$ & $\begin{array}{l}12.1808 \\
14.6163\end{array}$ & $\begin{array}{l}11.8383 \\
9.8259\end{array}$ & $\begin{array}{l}12.2783 \\
10.3607\end{array}$ \\
\hline $\begin{array}{l}\text { MI1 } \\
.2378 \\
.9816 \\
.5403\end{array}$ & $\begin{array}{l}17.0457 \\
7.0344 \\
8.6204\end{array}$ & $\begin{array}{l}16.8117 \\
4.6903 \\
8.1051\end{array}$ & $\begin{array}{l}16.0815 \\
3.8838 \\
6.6656\end{array}$ & $\begin{array}{l}2926 \\
1331 \\
5258\end{array}$ & $\begin{array}{l}8.8724 \\
3.2223 \\
5.7374\end{array}$ & $\begin{array}{l}8.6128 \\
2.5242 \\
7.5189\end{array}$ & $\begin{array}{l}7697 \\
.7022 \\
.2786\end{array}$ \\
\hline $\begin{array}{l}\text { ITGA2-B } \\
5.3028 \\
13.1184 \\
3.9557\end{array}$ & $\begin{array}{l}11.0373 \\
5.1924 \\
13.4129\end{array}$ & $\begin{array}{l}1.6504 \\
1226 \\
3.0793\end{array}$ & $\begin{array}{l}10.8464 \\
4.0247 \\
6.6071\end{array}$ & & & $\begin{array}{l}.4826 \\
.6185 \\
.1531\end{array}$ & $\begin{array}{l}.9472 \\
.9329 \\
.7657\end{array}$ \\
\hline $\begin{array}{l}13.2782 \\
10.7283 \\
4.6180\end{array}$ & $\begin{array}{l}12.5047 \\
14.2574 \\
12.2185\end{array}$ & & & & & $\begin{array}{l}3.8288 \\
.9153 \\
.9503\end{array}$ & $\begin{array}{l}2.7473 \\
.9926 \\
.9813\end{array}$ \\
\hline $\begin{array}{l}\text { STIL } \\
7.0348 \\
10.6395 \\
6.3377\end{array}$ & $\begin{array}{l}16.3427 \\
7.6268 \\
10.7712\end{array}$ & $\begin{array}{l}914 \\
92 \\
35\end{array}$ & & & & $\begin{array}{l}236 \\
63 \\
37\end{array}$ & $\begin{array}{l}.8353 \\
.0633 \\
.3526\end{array}$ \\
\hline $\begin{array}{l}4.5186 \\
5.1602 \\
5.2251\end{array}$ & $\begin{array}{l}13.6601 \\
5.4457 \\
6.6672\end{array}$ & $\begin{array}{l}3.9053 \\
.7680 \\
.9113\end{array}$ & $\begin{array}{l}3.2368 \\
.0804 \\
.8607\end{array}$ & & & $\begin{array}{l}.3449 \\
.3571 \\
.6609\end{array}$ & $\begin{array}{l}.9774 \\
.4477 \\
.9222\end{array}$ \\
\hline $\begin{array}{l}\text { GATA2 } \\
7.1197 \\
6.1647 \\
7.2164\end{array}$ & $\begin{array}{l}10.4935 \\
7.9526 \\
6.3061\end{array}$ & $\begin{array}{l}.8050 \\
5856 \\
0153\end{array}$ & & & & $\begin{array}{l}597 \\
09 \\
35\end{array}$ & $\begin{array}{l}9024 \\
3838 \\
4898\end{array}$ \\
\hline $\begin{array}{l}\text { CD19 } \\
17.1308 \\
17.7611 \\
12.0759\end{array}$ & $\begin{array}{l}17 . \\
17 . \\
-2 .\end{array}$ & $\begin{array}{l}10 . \\
16.2 \\
-2.2\end{array}$ & $\begin{array}{l}13.6 \\
-4.6\end{array}$ & $\begin{array}{l}19.5774 \\
15.0616 \\
14.0062\end{array}$ & & & \\
\hline $\begin{array}{l}\text { CD3G } \\
13.6161\end{array}$ & & & & & & & $\begin{array}{l}808 \\
07\end{array}$ \\
\hline $\begin{array}{l}18.7183 \\
0.9678\end{array}$ & & 78 & 14 & 05 & 33 & 12 & 54 \\
\hline NTT & & & & & & & $\begin{array}{l}103 \\
437\end{array}$ \\
\hline 14.6277 & 13 & 28 & 56 & & 05 & & 2 \\
\hline
\end{tabular}


bioRxiv preprint doi: https://doi.org/10.1101/177691; this version posted August 21, 2017. The copyright holder for this preprint (which was not certified by peer review) is the author/funder. All rights reserved. No reuse allowed without permission.

\begin{tabular}{|c|c|c|c|c|c|}
\hline CMYC & $\begin{array}{l}\text { hiPSCs } \\
6.23\end{array}$ & $\begin{array}{l}\text { APNLR+ } \\
5.04\end{array}$ & $\begin{array}{l}\text { APNLR- } \\
4.58\end{array}$ & $\begin{array}{l}\text { D17 EBs } \\
4.21\end{array}$ & $\begin{array}{l}\text { CD34 } \\
6.66\end{array}$ \\
\hline HOXB4 & 8.52 & 6.52 & 5.58 & 4.57 & 6.66 \\
\hline LIN28 & -1.89 & 1.54 & 2.04 & -2.89 & -7.25 \\
\hline NANOG & -2.38 & 1.71 & 2.77 & 0.68 & -9.33 \\
\hline P0U5F & -6.44 & 2.96 & 1.48 & 3.42 & -8 \\
\hline SoX2 & -3.02 & 0.37 & 0.76 & 2.71 & -8 \\
\hline FUT4 & -2.85 & 2.94 & 4.19 & 0.24 & -4. \\
\hline APNLR & 9.80 & 10.43 & 12.16 & 15.19 & 7.00 \\
\hline BMI1 & 9.80 & 7.46 & 6.32 & 6.23 & 7.00 \\
\hline ITGA2B & 3.54 & 6.48 & 4.70 & 6.66 & 1.54 \\
\hline MP01 & 5.23 & 4.81 & 5.92 & 7.41 & 7.00 \\
\hline STIL & 9.80 & 10.15 & 11.72 & 8.54 & 7.00 \\
\hline KIT & 7.91 & 4.40 & 3.01 & 4.02 & 7.0 \\
\hline GATA2 & 9.80 & 7.12 & 6.10 & 7.38 & 5.51 \\
\hline CD19 & 9.80 & 10.43 & 12.16 & 17.00 & -0.90 \\
\hline CD3G & 9.80 & 10.43 & 12.16 & 14.13 & 7.0 \\
\hline NCAM & 5.42 & 4.55 & 2.60 & 4.50 & 7.6 \\
\hline PECAM & 9.80 & 5.11 & 6.54 & 6.36 & 7.0 \\
\hline PTPRC & 1.43 & 8.82 & 8.08 & 5.42 & -2.89 \\
\hline RORC & 9.80 & 10.43 & 12.16 & 17.02 & 7.0 \\
\hline ERG & 9.31 & 6.26 & 9.52 & 10.62 & $3.1 \varepsilon$ \\
\hline GATA3 & 11.81 & 7.40 & 9.77 & 9.78 & 6.66 \\
\hline HOXA9 & 9.31 & 7.84 & 9.77 & 10.66 & 4.61 \\
\hline IRF8 & 10.45 & 4.50 & 8.88 & 9.27 & 4.33 \\
\hline KDR & 5.58 & 3.71 & 9.77 & 2.90 & 6.66 \\
\hline MITF & 6.74 & 7.41 & 8.55 & 5.44 & 6.66 \\
\hline MLLT3 & 7.16 & 2.57 & 6.06 & 2.93 & 6.66 \\
\hline RBPMS & 6.41 & 4.79 & 7.63 & 4.78 & 6.66 \\
\hline RUNX1 & 6.17 & 0.36 & 3.81 & 2.01 & 2.98 \\
\hline TEK & 9.05 & 4.52 & 9.77 & 5.59 & 6. \\
\hline HMG & 0.10 & -0.16 & -0.29 & 8.69 & 6.66 \\
\hline HOPX & 7.72 & 4.97 & 4.49 & 12.11 & 2.71 \\
\hline LEF1 & 6.21 & 4.57 & 5.98 & 9.50 & 4.61 \\
\hline MEIS & 6.72 & 4.10 & 3.71 & 8.09 & 6.66 \\
\hline MYB & 6.21 & 7.03 & 6.71 & 12.30 & 4.61 \\
\hline NKX & 8.61 & 7.73 & 6.71 & 13.66 & 6.66 \\
\hline PRDM & 7.28 & 2.69 & 2.04 & 7.66 & 6.66 \\
\hline N0S3 & 9.73 & 7.73 & 5.46 & 9.55 & 6.6 \\
\hline SOX4 & 5.90 & 7.73 & 5.46 & 6.98 & 3.61 \\
\hline CEPBA & -1.83 & -3.41 & -3.45 & -4.20 & -8.86 \\
\hline HLF & 9.10 & 7.73 & 5.46 & 10.47 & 6.6 \\
\hline RORA & 5.90 & 7.73 & 5.46 & 10.47 & 4.6 \\
\hline EPOR & 6.64 & 6.64 & 3.22 & 6.86 & 3.05 \\
\hline GATA1 & 12.99 & 7.96 & 6.79 & 10.16 & 7.06 \\
\hline IKZ & 8.58 & 6.35 & 5.98 & 8.66 & 6.19 \\
\hline KLF1 & 12.17 & 13.84 & 5.12 & 13.17 & 4.57 \\
\hline MATK & 10.83 & 8.93 & 5.93 & 9.28 & 2.80 \\
\hline MPL1 & 16.29 & 11.74 & 6.79 & 13.12 & 6.08 \\
\hline NFIB & 4.84 & 3.32 & 2.21 & 3.43 & 4.61 \\
\hline RAG2 & 3.64 & -2.64 & -0.40 & -2.60 & -5.56 \\
\hline SPIB & -1.82 & 11.27 & 6.79 & 11.31 & -3.6 \\
\hline HLF & 9.10 & 7.73 & 46 & 47 & 6.66 \\
\hline
\end{tabular}

